\title{
Analysis of elevated springtime levels of Peroxyacetyl nitrate (PAN) at the high Alpine research sites Jungfraujoch and Zugspitze
}

\author{
S. Pandey Deolal ${ }^{1}$, S. Henne ${ }^{2}$, L. Ries ${ }^{3}$, S. Gilge ${ }^{4}$, U. Weers ${ }^{1}$, M. Steinbacher ${ }^{2}$, J. Staehelin ${ }^{1}$, and T. Peter ${ }^{1}$ \\ ${ }^{1}$ Institute for Atmospheric and Climate Science, Swiss Federal Institute of Technology (ETH), Zurich, Switzerland \\ ${ }^{2}$ Laboratory for Air Pollution/Environmental Technology, Swiss Federal Laboratories for Materials Science and \\ Technology (Empa), Dübendorf, Switzerland \\ ${ }^{3}$ Air Monitoring Network, Environment Agency Germany (UBA), Platform Zugspitze Schneefernerhaus (ZSF) of \\ GAW-Global Station Zugspitze/Hohenpeissenberg, Germany \\ ${ }^{4}$ Hohenpeissenberg Meteorological Observatory, German Meteorological Service (DWD), Hohenpeissenberg, Germany
}

Correspondence to: J. Staehelin (johannes.staehelin@env.ethz.ch)

Received: 3 April 2014 - Published in Atmos. Chem. Phys. Discuss.: 20 May 2014

Revised: 8 October 2014 - Accepted: 16 October 2014 - Published: 28 November 2014

\begin{abstract}
The largest atmospheric peroxyacetyl nitrate (PAN) mole fractions at remote surface sites in the Northern Hemisphere are commonly observed during the months April and May. Different formation mechanisms for this seasonal maximum have previously been suggested: hemisphericscale production from precursors accumulated during the winter months, increased springtime transport from up-wind continents or increased regional-scale production in the atmospheric boundary layer from recent emissions. The two high Alpine research sites Jungfraujoch (Switzerland) and Zugspitze (Germany) exhibit a distinct and consistent springtime PAN maximum. Since these sites intermittently sample air masses of free-tropospheric and boundary layer origin, they are ideally suited to identify the above-mentioned PAN formation processes and attribute local observations to these. Here we present a detailed analysis of PAN observations and meteorological conditions during May 2008 when PAN levels were especially elevated at both sites. The highest PAN concentrations were connected with anticyclonic conditions, which persisted in May 2008 for about 10 days with north-easterly advection towards the sites. A backward dispersion model analysis showed that elevated PAN concentrations were caused by the combination of favourable photochemical production conditions and large precursor concentrations in the European atmospheric boundary layer. The results suggest that the largest PAN values in spring 2008 at
\end{abstract}

both sites were attributable to regional-scale photochemical production of PAN in the (relatively cold) planetary boundary layer from European precursors, whereas the contribution of inter-continental transport or free-tropospheric buildup was of smaller importance for these sites.

\section{Introduction}

Peroxyacetyl nitrate (PAN) is a key compound of reactive nitrogen species $\left(\mathrm{NO}_{\mathrm{y}}\right)$ formed by photo-oxidation and has a significant effect on the global distribution of tropospheric ozone (Fischer et al., 2014). PAN plays an important role in the complex radical chemistry of the troposphere because it acts as a relatively long-lived reservoir for nitrogen oxides $\left(\mathrm{NO}_{\mathrm{x}}\right)$ and reactive organic radicals. At cold temperatures PAN can be transported over long distances and, hence, contribute to inter-continental transport of $\mathrm{O}_{3}$ precursors (Penkett and Brice, 1986; Nielsen et al., 1981; Rappenglück et al., 2010; Schrimpf et al., 1998; Tsalkani et al., 1991). It is well known that PAN exhibits a strong seasonal cycle, peaking in spring in the northern hemispheric remote atmosphere (Moxim et al., 1996). These PAN spring maxima were often explained in the following way: the mixing ratios of long-lived NMVOC (non-methane volatile organic compounds) accumulate in the free troposphere (FT) over the 
winter season due to less efficient photo-degradation (Penkett et al., 1993); in early spring photochemistry becomes active and the accumulated NMVOC in the northern FT foster the build-up of PAN and $\mathrm{O}_{3}$ leading to the observed maximum in both species in the background troposphere (Penkett and Brice, 1986; Monks, 2000; Zanis et al., 2003, 2007; Fenneteaux et al., 1999). The seasonal pattern indicated by these studies leads to the perception that the spring maximum is not directly influenced by recent emissions into the planetary boundary layer (PBL) but is a background air phenomenon. In contrast, there are other studies explaining PAN spring maxima in terms of long-range transport or special meteorological situations (Fischer et al., 2010; Ridley et al., 1998) or a combination of both free-tropospheric and PBL air masses (Bottenheim et al., 1994).

PAN measurements reported during the period 1987-1988 from three Swiss sites (suburban station, Dübendorf, $431 \mathrm{~m}$ a.s.l. (above sea level); forest site, Lägeren, 685 ma.s.1.; Alpine valley site, Davos, 1630 ma.s.1.) showed significant seasonal variation in PAN with elevated monthly mean values in spring for all the stations, suggesting that maximum PAN concentrations were associated with anticyclonic weather types and low wind speeds (Wunderli and Gehrig, 1991). Previous PAN observations at the Swiss high Alpine site Jungfraujoch (JFJ) revealed maximum PAN levels $>1 \mathrm{ppb}$ in spring-summer season and attributed the maxima to thermally induced transport from the PBL (Zellweger et al., 2003).

Based on the above discussion there are three hypotheses for the origin of the PAN spring maximum at remote and high altitude sites in Europe:

1. increased background concentrations: build-up of precursor during winter in the Northern Hemisphere, active photochemistry producing high PAN concentrations in spring in the free troposphere;

2. boundary layer influence and meteorologically favourable situations: transport from the boundary layer, e.g. by convective transport and/or accumulation in anticyclonic airflow;

3. inter-continental transport: increased background mixing ratios (e.g. for ozone) from inter-continental transport during spring as shown by recent studies (Cooper et al., 2001, 2004, 2010; Fiore et al., 2009).

Fischer et al. (2014) used sophisticated numerical simulations that described aircraft measurements quite well but underestimated the PAN spring maxima at the Alpine sites Jungfraujoch (Switzerland) and Zugspitze (Germany) by more than a factor of 2 (see their Fig. S2 in the Supplement). The large deviation between these GEOS-Chem (Goddard Earth Observing System Chemistry transport model) simulations (based on a grid resolution of $2^{\circ} \times 2.5^{\circ}$ ) and measurements might be caused by the inappropriate description of the effect of European emissions for PAN concentration at Jungfraujoch. The study of Pandey Deloal et al. (2013), in which long-range backward-trajectory analysis (performed by LAGRANTO using ERA interim wind fields) together with chemical filters was applied covering the years 1997, 1998, 2008, 2009 and 2010, signifies that the largest springtime PAN concentrations observed at Jungfraujoch might originate from European emission of PAN precursors. However, the study of Pandey Deolal et al. (2013) was based on LAGRANTO backward-trajectory analysis which utilised coarse meteorological input data and did not describe turbulent and convective vertical transport. Therefore, the study could only provide qualitative and suggestive information regarding the mechanisms responsible for high springtime PAN concentration at Jungfraujoch.

The aim of the present study is to use more adequate transport simulations (FLEXPART (flexible particle dispersion model) with finer resolution input and treatment of turbulent and convective vertical transport) combined with a state-of-the-art transport categorisation to verify the tentative interpretation of Pandey Deolal et al. (2013), allowing for a more precise and more detailed description of the involved atmospheric physical processes and their relations. In addition, we extend the analysis by incorporating observations from another European high altitude site (Zugspitze) which showed a similar annual PAN cycle as Jungfraujoch. Here we can show that the PAN formation mechanisms are similar for both sites, allowing for a more generalised view than previously for Jungfraujoch only. We limit the analysis to the month of May 2008, when particularly large PAN mole fractions were reported at both sites. In addition, observations from nearby elevated rural sites (Rigi and Chaumont, Switzerland; Hohenpeissenberg, Germany), which are more representative for the daytime PBL, are used to further interpret the processes responsible for the build-up of large PAN mole fractions.

\section{Site characterisation and measurements}

The main sites used in this study (Jungfraujoch and Zugspitze, but also the PBL site Hohenpeissenberg) are so-called global stations of the Global Atmosphere Watch (GAW) programme of the World Meteorological Organization (WMO), while the two additional Swiss sites are regional (Rigi) and contributing (Chaumont) stations to GAW. For all sites detailed measurement and site information can be found in the GAW station information system (GAWSIS; http://gaw.empa.ch/gawsis). The Swiss sites are also part of the Swiss National Air Pollution Monitoring Network (NABEL), which is operated by the Swiss Federal Laboratories for Materials Science and Technology (Empa) in collaboration with the Swiss Federal Office for Environment (FOEN) (Empa and FOEN, 2013). The measurements at Zugspitze are supported by the Federal Environment Agency 
(UBA) and regular monitoring of meteorological parameters and atmospheric radioactivity is performed by the German Weather Service (DWD). Continuous measurements of relevant gaseous species and aerosols are performed at all sites. An overview of all the sites is provided in Table 1 and their locations are shown in Fig. 1.

\subsection{Site characterisation}

\subsubsection{High Alpine sites - Jungfraujoch (JFJ) and Zugspitze (ZSF)}

The observatory at Jungfraujoch (Sphinx observatory, $3580 \mathrm{~m}$ a.s.1.) is situated between the Mönch and the Jungfrau mountains in the Bernese Alps of Switzerland. The site is intermittently influenced by the lower FT and European PBL air and, therefore, provides the opportunity to characterise air masses with very different origin and air mass history. Air arriving from the north is often influenced by surface contact over the Swiss plateau before reaching JFJ, while air masses arriving from the south are often advected from the Po Valley crossing the inner Alpine region (Parker et al., 2009; Zellweger et al., 2003).

The Zugspitze Schneefernerhaus (ZSF, 2670 m a.s.1.) observatory is situated in southern Germany at the northern rim of the Alps. Therefore, it is suitable for the detection of air masses advected from the north (Kaiser et al., 2007). The measurement station is situated on the southern slope of Zugspitze between the summit and a skiing area. Normally, Zugspitze receives free-tropospheric air but, similar to JFJ, the site is frequently exposed to boundary layer air in summer time due to thermally induced flow systems (Gantner et al., 2003; Reiter et al., 1987). In comparison to JFJ, a stronger influence of surface emissions on the trace gas observations at ZSF was deduced and the site was placed into a different category (weakly influenced) as JFJ (mostly remote) in a study categorising remote air quality sampling sites in Europe (Henne et al., 2010). The altitude difference between the two sites is $\sim 900 \mathrm{~m}$, while the horizontal distance is $\sim 250 \mathrm{~km}$.

\subsubsection{PBL sites - Hohenpeissenberg (HPB), Rigi (RIG) and Chaumont (CHA)}

The Hohenpeissenberg observatory (HPB) is another GAW site located in Germany, about $40 \mathrm{~km}$ north of Zugspitze in a hilly area dominated by agriculture and forests. The site is predominantly situated in the daytime PBL and night-time residual layer as it is located on top of a small mountain (985 $\mathrm{m}$ a.s.1.) and about $300 \mathrm{~m}$ above the surrounding area.

The station Rigi (RIG) (1031 ma.s.l.) is situated on the northern slope of the Rigi mountain, in an elevated rural environment $600 \mathrm{~m}$ above Lake Lucerne. The site is surrounded by grassland and forest areas and small cities such as Zug and Lucerne are approximately $12 \mathrm{~km}$ away from the site

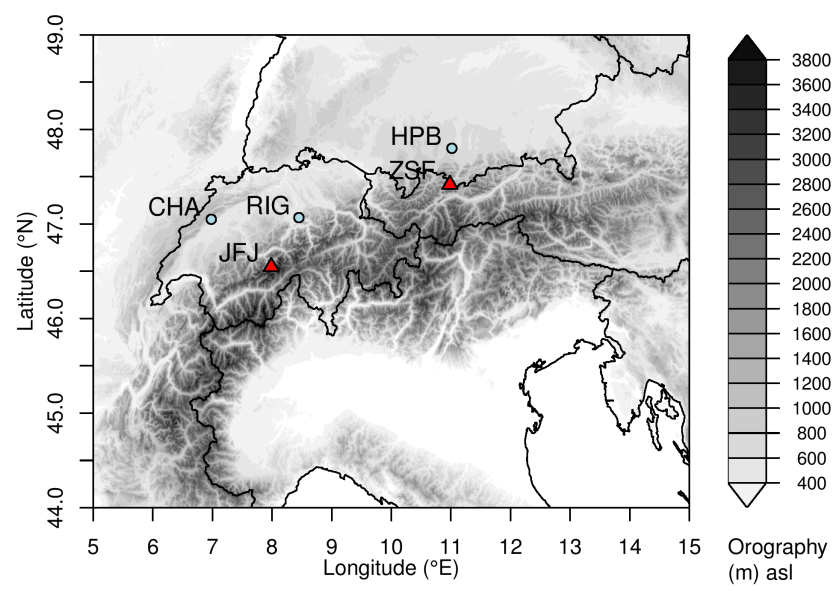

Figure 1. Locations of the sites. Red triangles: locations of the two high Alpine stations Jungfraujoch (JFJ) and Zugspitze Schneefernerhaus (ZSF). Blue circles: the additional elevated PBL sites Chaumont (CHA), Rigi (RIG) and Hohenpeissenberg (HPB).

and at considerably lower elevation. Rigi is located about $65 \mathrm{~km}$ north-east of JFJ. The Chaumont observatory (CHA) (1136 m a.s.1.) is located about $700 \mathrm{~m}$ above Lake Neuchâtel. The area is dominated by meadows and pastures. The city of Neuchâtel is situated about $5 \mathrm{~km}$ south of the station, but well below at the lake shore. The station is located about $90 \mathrm{~km}$ north-west of JFJ. Both Swiss sites can be expected to be within the daytime PBL during the spring and summer months, while they are more decoupled from lowland influences during night and winter.

\subsection{Trace gas measurements}

\subsubsection{Jungfraujoch (JFJ)}

The air was sampled from the main inlet dedicated for trace gas observations, which has a total length of about $3 \mathrm{~m}$, with $2 \mathrm{~m}$ on the roof top and $1 \mathrm{~m}$ inside the laboratory. The inlet consists of stainless steel tubing with an inner diameter of $90 \mathrm{~mm}$ and is constantly heated to $10^{\circ} \mathrm{C}$. The airflow rate was $50 \mathrm{~m}^{3} \mathrm{~h}^{-1}$. The PAN instrument was directly connected to the main inlet using PFA tubing. Since PAN measurements are sensitive to temperature, the instrument was placed close to the main inlet avoiding further heating to laboratory temperatures.

PAN measurements were performed at JFJ using a commercial gas chromatograph (GC) analyser and a calibration unit provided by Meteorologie Consult $\mathrm{GmbH}$ (Metcon). The technique is based on chromatographic separation with subsequent detection and quantification by an electron capture detector (ECD); for more details see Pandey Deolal et al. (2013). Other trace gases such as total reactive nitrogen species $\left(\mathrm{NO}_{\mathrm{y}}\right)$, nitrogen oxides $\left(\mathrm{NO}_{\mathrm{x}}\right), \mathrm{CO}$ and $\mathrm{O}_{3}$ are routinely monitored as part of the NABEL monitoring network (Empa and FOEN, 2013). $\mathrm{NO}_{\mathrm{y}}, \mathrm{NO}_{\mathrm{x}}$ and $\mathrm{NO}$ measurements 
at JFJ were performed using high sensitive analysers (ECO physics CLD 89p) based on a chemiluminescence technique. More details are presented in Pandey Deolal et al. (2012). CO measurements were performed using a commercially available instrument (APMA-370, Horiba) based on nondispersive infrared absorption (NDIR). Ozone was measured using a commercially available monitor (Thermo Environmental Instruments, Model 49C, UV absorption). The measurements of $\mathrm{CO}$ and $\mathrm{O}_{3}$ are described in more detail in Zellweger et al. (2003, 2009).

\subsubsection{Zugspitze (ZSF)}

The air was sampled with the UBA steel inlet used for measuring reactive gases. The total length of the inlet is $3.5 \mathrm{~m}$ with $2.25 \mathrm{~m}$ on the roof top and $1.25 \mathrm{~m}$ inside the laboratory. A borosilicate glass tube was placed inside the steel inlet with inner glass diameter of $80 \mathrm{~mm}$. The inlet is constantly heated to $+6{ }^{\circ} \mathrm{C}$. The airflow rate was $22.9 \mathrm{~L} \mathrm{~min}^{-1}$.

PAN measurements at ZSF were performed using the same technique and instrument as described for JFJ measurements. $\mathrm{NO}_{\mathrm{y}}$ and $\mathrm{NO}$ measurements were performed using CRANOX, ECO physics (2x CLD 770 AL pptv) containing a gold converter and two reaction chambers. The gold converter is heated to $300^{\circ} \mathrm{C}$ with $2 \% \mathrm{CO}\left(99.997 \%\right.$, Air Liquide). $\mathrm{NO}_{\mathrm{x}}$ was measured as NO after the photolytic conversion by the photolytic converter (PLC $760 \mathrm{MH}$ ) instrument. The converter efficiency of the gold converter mainly ranged between 95 and $98 \%$ and conversion efficiency of PLC ranged from 61 to $82 \%$. The detection limit for $\mathrm{NO}_{\mathrm{y}}$ and $\mathrm{NO}$ channel was 50 pptv. The time resolution of these measurements was $145 \mathrm{~s}$. Calibrations were performed twice a week. The typical drift of the calibration span signal for NO during four days was $1.1-1.4 \%$.

\subsubsection{Hohenpeissenberg (HPB)}

PAN measurements at this site were started in the late 1990s and continued till present, using the same equipment as for JFJ and ZSF. Additionally, the PAN measurements at HPB have been quality tested by at a blind inter-comparison experiment at NCAR, Boulder, CO (Tyndall et al., 2005). Longterm analysis of $\mathrm{CO}$, nitrogen dioxide $\left(\mathrm{NO}_{2}\right)$ and $\mathrm{O}_{3}$ time series was reported by Gilge et al. (2010), where these measurements were also compared with the other Alpine sites JFJ, ZSF and Hoher Sonnblick.

\subsubsection{Rigi (RIG) and Chaumont (CHA)}

A variety of trace gases and aerosol parameters (such as $\mathrm{NO}_{2}$, $\mathrm{O}_{3}$, particulate matter and volatile organic compounds, VOC) as well as meteorology are routinely performed at Rigi and Chaumont (Empa and FOEN, 2013).

\section{Transport analysis}

\subsection{Backward dispersion simulations}

The Lagrangian particle dispersion model (LPDM) FLEXPART (Version 8.1) (Stohl et al., 2005) was used to calculate source receptor relationships (SRRs) for May 2008 measurements for the two high Alpine sites. For each 3hourly interval, 50000 particles were released at each receptor site (JFJ and ZSF) and traced back in time for 10 days considering the mean flow, turbulent PBL flow and deep convection. The model was driven by European Centre for Medium Range Weather Forecast (ECMWF) operational analyses (00:00, 06:00, 12:00, 18:00 UTC) and forecasts $(03: 00,09: 00,15: 00,21: 00$ UTC) with 91 vertical level and a horizontal resolution of $1^{\circ} \times 1^{\circ}$ for the global domain and $0.2^{\circ} \times 0.2^{\circ}$ for a nested domain covering the Alpine area $\left(4^{\circ} \mathrm{W}-16^{\circ} \mathrm{E}, 39-51^{\circ} \mathrm{N}\right)$. Compared to the aforementioned study by Pandey Deolal et al. (2013), which drew its conclusions from single-trajectory simulations, the present transport simulations are better suited to quantitatively capture the influence of the European PBL on the observations at the high Alpine sites since FLEXPART explicitly simulates turbulent and convective mixing that cannot be represented in single-trajectory models.

Release heights of 3000 and $2500 \mathrm{~m}$ were chosen for JFJ and ZSF, respectively. This is significantly lower than the true altitudes of the observatories and takes into account the limited horizontal resolution of the model, by which the Alpine topography is not well represented, requiring a release height somewhere between the station's real altitude and the model ground (Brunner et al., 2012; Keller et al., 2012).

The simulated SRRs allow directly linking a mass release at a source grid cell with a mass mixing ratio at the receptor (Seibert and Frank, 2004). SRRs are given in units $\mathrm{s} \mathrm{m}^{3} \mathrm{~kg}^{-1}$ and are also referred to as footprints and emission sensitivities. SRRs were generated on a regular grid with $0.1^{\circ} \times 0.1^{\circ}$ covering Western Europe (Fig. 4) and a secondary grid with $0.5^{\circ} \times 0.5^{\circ}$ horizontal resolution covering the larger North Atlantic region (see Fig. S1). The vertical resolution of both grids was restricted to 10 levels up to $15 \mathrm{~km}$ above model ground, the lowest of these with a $100 \mathrm{~m}$ thickness above ground.

\subsection{Footprint clustering}

In order to see the effects of different flow regimes on PAN concentrations, simulated SRRs were classified into different flow regimes applying clustering methods to the transport simulations but not to the observed trace species. A straightforward approach would be to treat the SRR in every cell of the output grid as an individual time series in the cluster analysis. However, in that case the number of variables would become too large to be handled efficiently and arbitrary results might be produced due to the inclusion of grid cells with very 
Table 1. Characteristics of measurement sites: high Alpine sites (Jungfraujoch, JFJ; Zugspitze Schneefernerhaus, ZSF) which are intermittently within the free troposphere (FT) and influenced by boundary layer injections, and elevated rural sites (Hohenpeissenberg, HPB; Rigi, RIG; Chaumont, CHA) which are usually situated within the daytime planetary boundary layer but well above the night-time inversion layer. The given temperature and ambient pressure levels give the range of the observations in May 2008.

\begin{tabular}{|c|c|c|c|c|c|}
\hline Parameter & $\begin{array}{r}\text { Jungfraujoch } \\
(\mathrm{JFJ})\end{array}$ & $\begin{array}{r}\text { Zugspitze/ } \\
\text { Schneefernerhaus } \\
(\mathrm{ZSF})\end{array}$ & $\begin{array}{r}\text { Hohenpeissenberg } \\
(\mathrm{HPB})\end{array}$ & $\begin{array}{r}\text { Rigi } \\
\text { (RIG) }\end{array}$ & $\begin{array}{r}\text { Chaumont } \\
\text { (CHA) }\end{array}$ \\
\hline Country & Switzerland & Germany & Germany & Switzerland & Switzerland \\
\hline Geographical coordinates & $46.33^{\circ} \mathrm{N} 7.59^{\circ} \mathrm{E}$ & $47.42^{\circ} \mathrm{N} 10.98^{\circ} \mathrm{E}$ & $47.80^{\circ} \mathrm{N} 11.02^{\circ} \mathrm{E}$ & $46.07^{\circ} \mathrm{N} 8.45^{\circ} \mathrm{E}$ & $47.02^{\circ} \mathrm{N} 6.58^{\circ} \mathrm{E}$ \\
\hline Altitude (m a.s.1.) & 3580 & 2670 & 985 & 1031 & 1137 \\
\hline Temperature $(\mathrm{K})$ & $260-274$ & $266-285$ & $277-300$ & $276-297$ & $274-295$ \\
\hline Pressure $(\mathrm{hPa})$ & 647-662 & $727-742$ & 895-912 & 890-907 & 879-895 \\
\hline Category & $\begin{array}{r}\text { high Alpine } \\
\text { (FT/PBL) }\end{array}$ & $\begin{array}{r}\text { high Alpine } \\
\text { (FT/PBL) }\end{array}$ & $\begin{array}{r}\text { elevated rural } \\
(\mathrm{PBL})\end{array}$ & $\begin{array}{r}\text { elevated rural } \\
(\mathrm{PBL})\end{array}$ & $\begin{array}{r}\text { elevated rural } \\
\text { (PBL) }\end{array}$ \\
\hline Measurement operation (trace gases) & Empa & UBA & DWD & Empa & Empa \\
\hline
\end{tabular}

small SRRs. Therefore, we reduced the number of grid cells by aggregating cells with small average (May 2008) emission sensitivities to larger grid cells. Starting from grid cells with $0.1^{\circ}$ resolution we allowed aggregation to grid cells with up to $3.2^{\circ}$ horizontal resolution. Only SRRs in the lowest output level were considered. This grid reduction is similar to the method that was used in regional inversion studies where it is beneficial to reduce the dimension of the inversion problem (Vollmer et al., 2009; Keller et al., 2011). We iteratively varied the SRR threshold for grid aggregation to obtain approximately 100 grid cells (cluster variables) for the calculation of the dissimilarity matrix required by the clustering algorithm. Only the European domain was considered for the clustering, which will focus the separation of flow situations more onto the continental-scale transport to the sites and to a lesser degree onto the inter-continental transport. However, as will be discussed in Sect. 4, the model results for May 2008 did not suggest any significant inter-continental transport from North America during this period; hence, the focus on the European domain is justified in this case. Since the time series of aggregated SSRs were not normally or log-normally distributed, we chose an alternative distance measure to obtain the dissimilarity matrix, $\mathbf{D}$ with elements $d_{i j}$. Instead of the usually applied Euclidean distance we calculated distribution independent absolute distances between the ranks of the SRRs within the time series

$d_{i j}=\sum_{l: 1, N}\left|\operatorname{rank}\left(\mathrm{SRR}_{l}\right)_{i}-\operatorname{rank}\left(\mathrm{SRR}_{l}\right)_{j}\right|$,

where index $l$ runs over all times $N$, and $i$ and $j$ refer to the individual grid cells. Here rank stands for the sample rank of values in a vector. If ties (same values within vector) existed, these would get an average rank. Once the dissimilarity matrix is formed, the clustering was done using $k$ medoids clustering (Kaufman and Rousseeuw, 1990). The number of clusters was obtained using the silhouette technique (Kaufman and Rousseeuw, 1990) by choosing the number of clusters (in the range 2 to 20) for which the average silhouette widths became maximal. The technique described here is similar to the one presented by Hirdman et al. (2010) for Arctic sites and essentially the same as applied by Sturm et al. (2013) to FLEXPART simulations for JFJ for a period of three years.

The clustering was applied to the time series of the aggregated emission sensitivities for both high Alpine sites separately. For JFJ the maximal silhouette width was at four clusters, while for ZSF the situation was more complicated. Here the overall maximum silhouette width was obtained for 18 clusters, which gave a much too fine separation of the transport situations. Other local maxima were at three and five clusters. The clustering with five clusters was more similar to the one obtained for JFJ. Hence, five clusters were retained for ZSF.

For each cluster, average surface SRRs were calculated by summation over all cluster members and division by the number of cluster members $\mathrm{N}_{\mathrm{c}}$

$\mathrm{RTC}_{i, j, k}^{\mathrm{c}}=\frac{\sum_{l \in C} \mathrm{SRR}_{i, j, k, l}}{N_{\mathrm{c}}}$,

where $i, j, k$ represent the spatial indices and $l$ the temporal. The index $\mathrm{c}$ identifies the cluster number.

\section{Results and discussion}

\subsection{Seasonal cycle of PAN}

PAN measurements from different sites are shown in Fig. 2. At JFJ, PAN measurements were performed during campaigns in 2008 for the spring-summer (May and August) and autumn (September and October) months. The monthly mean mixing ratios of PAN for both JFJ and ZSF are presented in Fig. 2, left (left panel). These measurements indicate a strong seasonal cycle in the PAN with peaking mole fractions in late spring (April or May) and minima in the autumn and winter months. Prior to recent measurements, PAN observations at JFJ from April 1997 to 

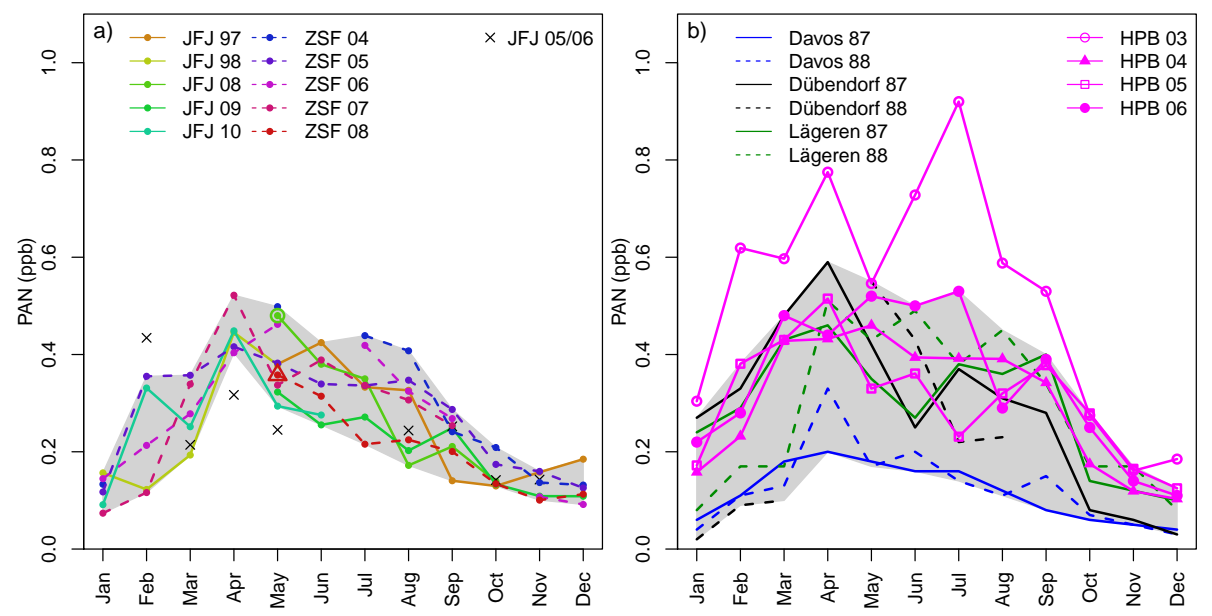

Figure 2. PAN mixing ratios. (a) Monthly mean PAN mixing ratios at high mountain sites Jungfraujoch (JFJ) and Zugspitze Schneefernerhaus (ZSF). Open green circle and open red triangle: monthly mean values at JFJ for May 2008. Black crosses: campaign measurements at JFJ during February 2005-August 2006 from (Balzani Lööv et al., 2008). The grey shaded area shows the measurement range of monthly averages based on continuous measurements of JFJ and ZSF. JFJ measurements from 2005 to 2006 were excluded from the shaded area because they did not cover a complete month. (b) PAN measurements of less elevated sites (Hohenpeissenberg, HPB) and PAN measurements during 1987-1988 from Wunderli and Gehrig (1991) for Swiss suburban (Dübendorf), rural (Lägeren) and low-level Alpine sites (Davos, $1630 \mathrm{~m}$ a.s.1.). The grey shaded area shows the measurement range based on all PAN measurements excluding 2003 which was an exceptional year due to a pronounced European heat wave.

May 1998 (black solid line) also revealed a similar annual cycle (Zellweger et al., 2000). PAN measurements at JFJ performed during campaigns between February 2005 and August 2006 (black crosses) by Balzani Lööv et al. (2008) indicated background mole fractions $<0.2 \mathrm{ppb}$ in April and May; however, spring mean mole fractions were found significantly lower than all other reported measurements. Campaign measurements during February-March 2003 at JFJ showed a mean concentration of $0.142 \mathrm{ppb}$ (Whalley et al., 2004), which is in agreement with the observations from other years; Fig. 2. (right panel) shows the PAN measurements at the PBL sites including HPB and the Swiss sites Dübendorf (sub-urban), Lägeren (rural forest) and Davos (Alpine valley, $1630 \mathrm{~m}$ a.s.l.) taken from Wunderli and Gehrig (1991). All these measurements in the PBL, also including the Alpine valley site, clearly show the same seasonal behaviour and are in line with previous observations of spring PAN maxima at northern hemispheric mid-latitudes (Penkett and Brice, 1986; Monks, 2000; Zanis et al., 2003, 2007; Fenneteaux et al., 1999). The only exceptions showing a summer maximum are the measurements of HPB in 2003 which are most probably caused by the special conditions of the European heat wave in summer 2003 (e.g. Ordóñez et al., 2010). The larger interannual PAN variability (even excluding 2003) at the PBL sites as compared to the high altitude sites can be explained by the stronger influence of variable meteorology on observed mole fractions close to the precursor emissions. Also note that the site Davos is a relatively remote site compared to the other PBL sites, explaining part of the suggested large interannual variability.
During May 2008 JFJ experienced some of the largest hourly PAN mixing ratios ever recorded at JFJ (Pandey Deolal et al., 2013) and also the monthly mean PAN was among the largest on record (see Fig. 2). PAN at ZSF was comparable to other years. Hence, May 2008 was selected for a more detailed analysis as the variability at the sites can help identifying the potential origin of air masses and meteorological processes involved.

Since high Alpine sites intermittently receive FT and PBL air, it should be possible to attribute high PAN observations to either the FT or PBL, if the air mass contributions can be clarified. Even on typical fair-weather days Jungfraujoch is usually not within the PBL, but it is rather only influenced by intermittent injections of PBL air into a secondary Alpine boundary layer (see Henne et al., 2004). This process can usually be seen by elevated late afternoon concentrations of typical primary PBL tracers like CO. Due to the relatively narrow horizontal extent of this injection layer JFJ comes back under free-tropospheric influence during the night. A strong subsidence during night-time, bringing ozone rich air to the site as observed at other, lower elevation mountain sites (Roberts et al., 1995), is usually not observed at JFJ or ZSF, with the limitation that the ZSF observatory is situated $910 \mathrm{~m}$ below JFJ. 


\subsection{Observations in May 2008}

\subsubsection{Meteorological conditions}

The entire month was characterized by an alternation between rather stagnant high and low-pressure systems over Europe. A low-pressure system with its centre over the North Sea and the UK prevailed from the beginning of the month until 5 May. From 6 to 11 May, distinct high pressure conditions developed over southern Scandinavia extending southward and eastward towards Central and Eastern Europe. This resulted in high irradiation and cloud-free conditions in Central Europe and parts of Eastern Europe, and this period was considered as blocking anticyclonic conditions (Hamburger et al., 2011). Towards the end of this period pressure gradients weakened and the deep convection potential increased resulting in local thunderstorms over the Alps and Jura mountains on 12 May. From 13 to 17 May the situation over Central and Western Europe was dominated by a low-pressure system moving from the Gulf of Biscay towards northern Germany. The Alpine area was influenced by the frontal systems embedded in this lower pressure system. As a result, irradiation (cloud cover) was reduced (enhanced) south and west of the Alps. A south foehn situation developed on 15 and 16 May with precipitation on the southern side of the Swiss Alps. From 17 to 31 May, low-pressure conditions persisted over Central Europe leading to a succession of frontal passages.

\subsubsection{Observations at Jungfraujoch and Zugspitze}

The time series of trace gas observations at JFJ and ZSF are shown in Fig. 3 for May 2008. The PAN mixing ratios at JFJ were especially high during the period 6-15 May reaching a 3-hourly maximum of $1.2 \mathrm{ppb}$. PAN was elevated during the same period at ZSF as well, but did not exceed $1 \mathrm{ppb}$.

In addition to PAN, other trace species such as $\mathrm{NO}_{\mathrm{y}}, \mathrm{CO}$ and $\mathrm{O}_{3}$ showed increased mixing ratios during this period at both sites as well, while $\mathrm{NO}_{\mathrm{x}}$ mixing ratios remained comparably low (Fig. 3). After 15 May PAN levels dropped at both sites and remained between 0.1 and $0.5 \mathrm{ppb}$ for the rest of the month.

In general PAN levels were lower (factor 0.7) and $\mathrm{NO}_{\mathrm{x}}$ and $\mathrm{NO}_{\mathrm{y}}$ levels were greater (factor 2.9 and 1.4, respectively) at ZSF as compared to JFJ. The monthly average contribution of PAN to total $\mathrm{NO}_{\mathrm{y}}$ was about 59 and $26 \%$ for JFJ and ZSF, respectively. Part of this difference may be related to the temperature difference between the sites and the connected difference in thermal decomposition of PAN. The average temperature of +1.5 and $-5.0^{\circ} \mathrm{C}$ at $\mathrm{ZSF}$ and JFJ, respectively, during the high PAN episode can be translated to average PAN lifetimes with respect to thermal decomposition of $\tau=\sim 1$ day and $\tau=\sim 5$ days for ZSF and JFJ, respectively. Temperature differences were reduced between 20 and 24 May but strongly increased after. However, over- all a weak negative correlation (Pearson correlation coefficient: $R=-0.17$ ) was observed between PAN differences and temperature differences between the sites. This is an indication, that temperature is only one factor influencing the PAN to $\mathrm{NO}_{\mathrm{y}}$ ratio which also depends on $\mathrm{NO}, \mathrm{NO}_{2}$ and organic radical availability during air mass aging, but could not be quantified in detail in the scope of this study.

$\mathrm{O}_{3}$ levels were generally greater at JFJ as compared with ZSF and specific humidity was generally smaller, most likely due to the higher altitude of the JFJ observatory. An exception to this observation is the period 3 to 6 May, when the lowest $\mathrm{O}_{3}$ mole fractions occurred during May 2008 at JFJ. At the same time $\mathrm{CO}$ levels were decreased and humidity increased. Unfortunately, PAN measurements are missing for 4 to 6 May at JFJ and, when looking at the PAN decrease on 3 May, it can only be assumed that PAN levels were low as well (supported by the fact that $\mathrm{NO}_{\mathrm{y}}$ mixing ratios remained low, too). Trace gas mole fractions at ZSF did not show any special event during the same period. Furthermore, an episode of high $\mathrm{NO}_{\mathrm{x}}$ mole fractions was observed at ZSF on 21 and 22 May, which is also reflected in relatively low $\mathrm{O}_{3}$ mole fractions at the same time and site.

\subsubsection{Footprint cluster analysis}

To further analyse the conditions that led to the observed variability in PAN observations and especially the period of elevated PAN, the trace gas time series were split into different categories according to the transport clustering described above (footprint clustering). Since the clustering is based on transport history of the observed air masses only, it is thought to shed light on the main question of this article as to which extent the observed spring maximum in PAN can be related to free-tropospheric, hemispheric background-scale production of PAN from accumulated precursors or regional-scale production from recent emissions.

As described above, the clustering resulted in four and five clusters for JFJ and ZSF, respectively. The results of the clustering in terms of temporal attribution can be seen in Fig. 3, in which the time series were coloured according to the transport cluster. It can directly be seen that the individual clustering at the sites resulted in relatively similar temporal cluster attributions at both sites. When considering that clusters 4 and 5 at ZSF could actually be joined to be comparable to cluster 4 at JFJ, the detected transport regimes match between the sites in $91 \%$ of all cases. Keeping in mind that the clustering relies on the simulated transport history only and not on the in situ observations, it is remarkable that the clustering excellently separates the episode of elevated levels from periods with low PAN. This in itself already indicates that large parts of the PAN variability actually depend on the transport history and may be explained by analysing the conditions during the different transport regimes in detail.

In the following, the observed time series are further interpreted following the obtained transport clustering. The 


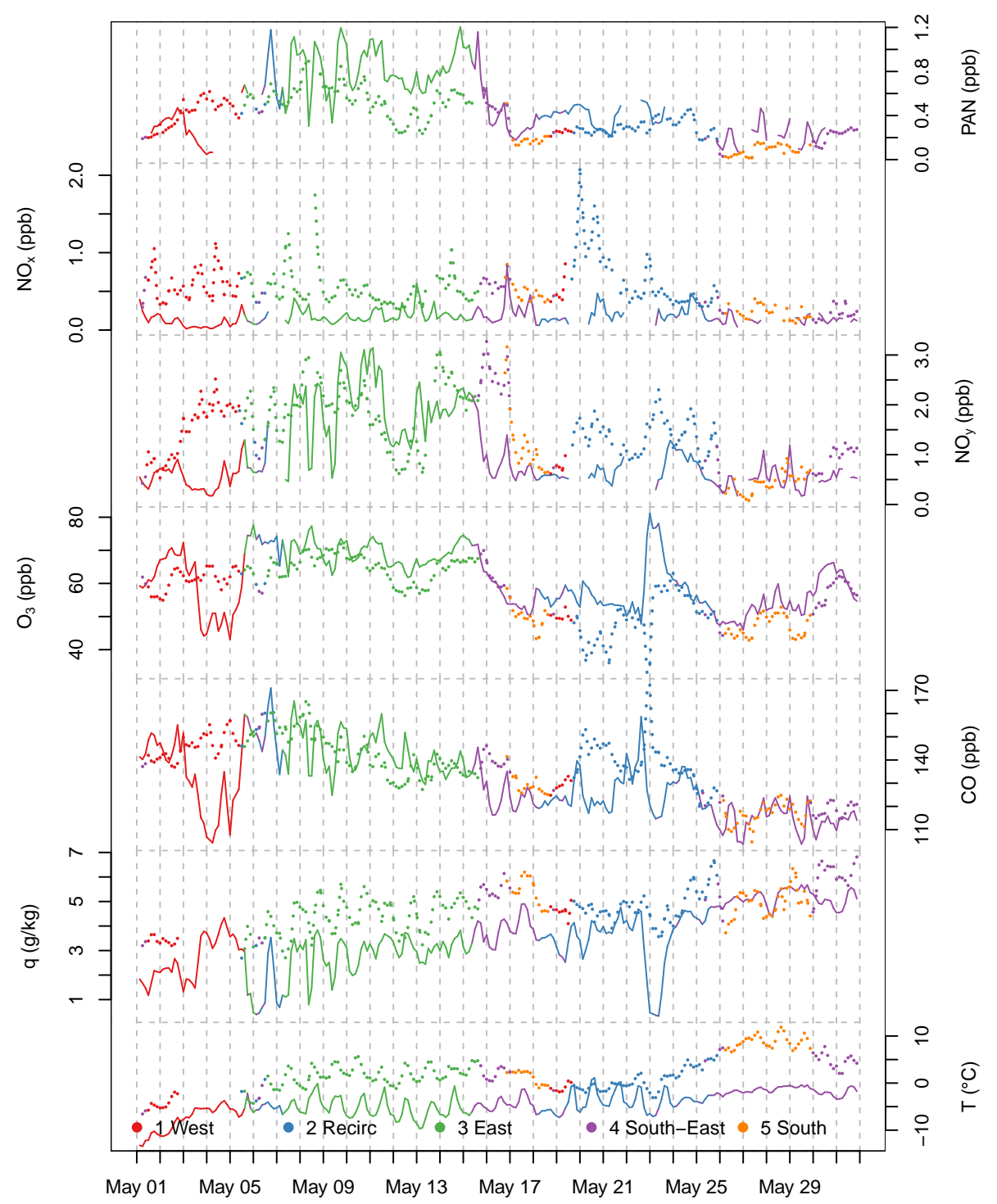

Figure 3. Observed 3-hourly averages of trace gas mixing ratios (ppbv), absolute humidity $\left(\mathrm{g} \mathrm{kg}^{-1}\right)$ and temperature (K) at (solid lines) Jungfraujoch and (dotted lines) Zugspitze in May 2008. The colour coding refers to the periods as identified by footprint clustering (see Sect. 4.2.3).

results of the latter are displayed in Figs. 4 and 5 as cluster average surface SRRs and cluster average latitude-altitude SRR distributions for the European domain, respectively. Similar figures for the larger North Atlantic region can be found in the Supplement (Figs. S1 and S2). In addition to the observed trace gas time series, the observations were split by transport cluster and aggregated to average diurnal cycles (Figs. 6 and 7). Where available, parameters from the less elevated sites, usually residing in the PBL or night-time residual layer, were treated in the same way, using the clustering as obtained for the nearby high Alpine site. For JFJ the average from the Swiss PBL sites (CHA and RIG) was taken, while for ZSF the observations from HPB were used as PBL reference. Observed $\mathrm{PAN}-\mathrm{CO}$, and $\mathrm{PAN}-\mathrm{O}_{3}$ relationships at the high Alpine sites, again disaggregated by transport cluster, are depicted in Fig. 8. Regression slopes were calculated from 3-hourly data using weighted total least-square regression (Krystek and Anton, 2007), which takes the measurement uncertainty of both variables into account.

In a simplified way correlations between $\mathrm{CO}$ and PAN can be understood as follows. Assuming a constant PAN and $\mathrm{CO}$ background, emissions will lead to an initial increase in $\mathrm{CO}$ and PAN precursors in an air mass. During transport from the source to the receptor, PAN may be produced under favourable conditions while $\mathrm{CO}$ can be assumed to remain relatively constant. During transport the original pollution plume will further mix with background air masses. The interception of different degrees of mixed air masses at 

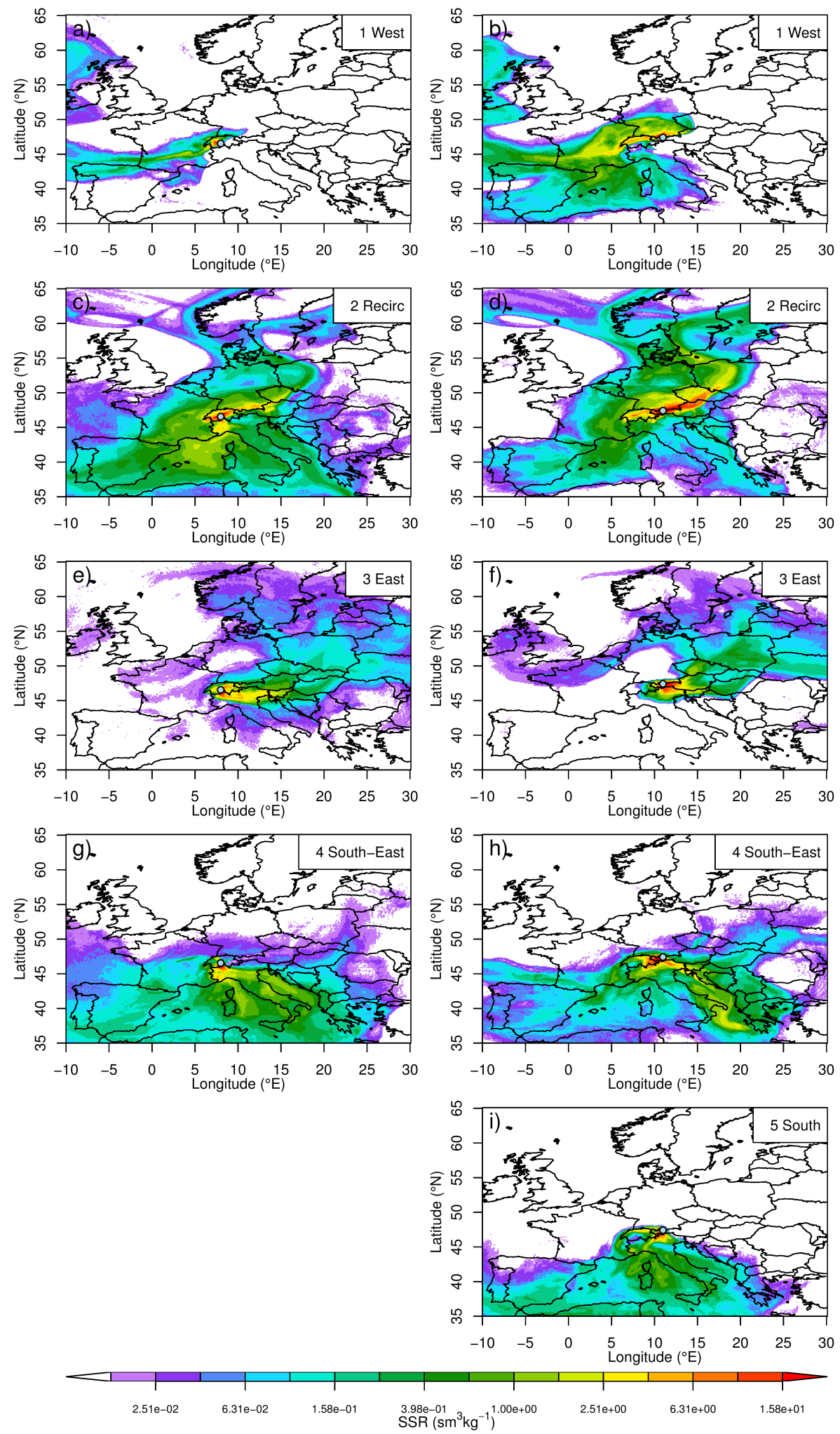

Figure 4. Cluster average surface source receptor relationships (SRRs) for (a, $\mathbf{c}, \mathbf{e}, \mathbf{g}) \mathrm{JFJ}$ and $(\mathbf{b}, \mathbf{d}, \mathbf{f}, \mathbf{h}, \mathbf{i})$ ZSF. Larger SRRs indicate a larger sensitivity of the samples air masses to surface fluxes (emissions or deposition). The sampling locations are given by a light blue circle. 

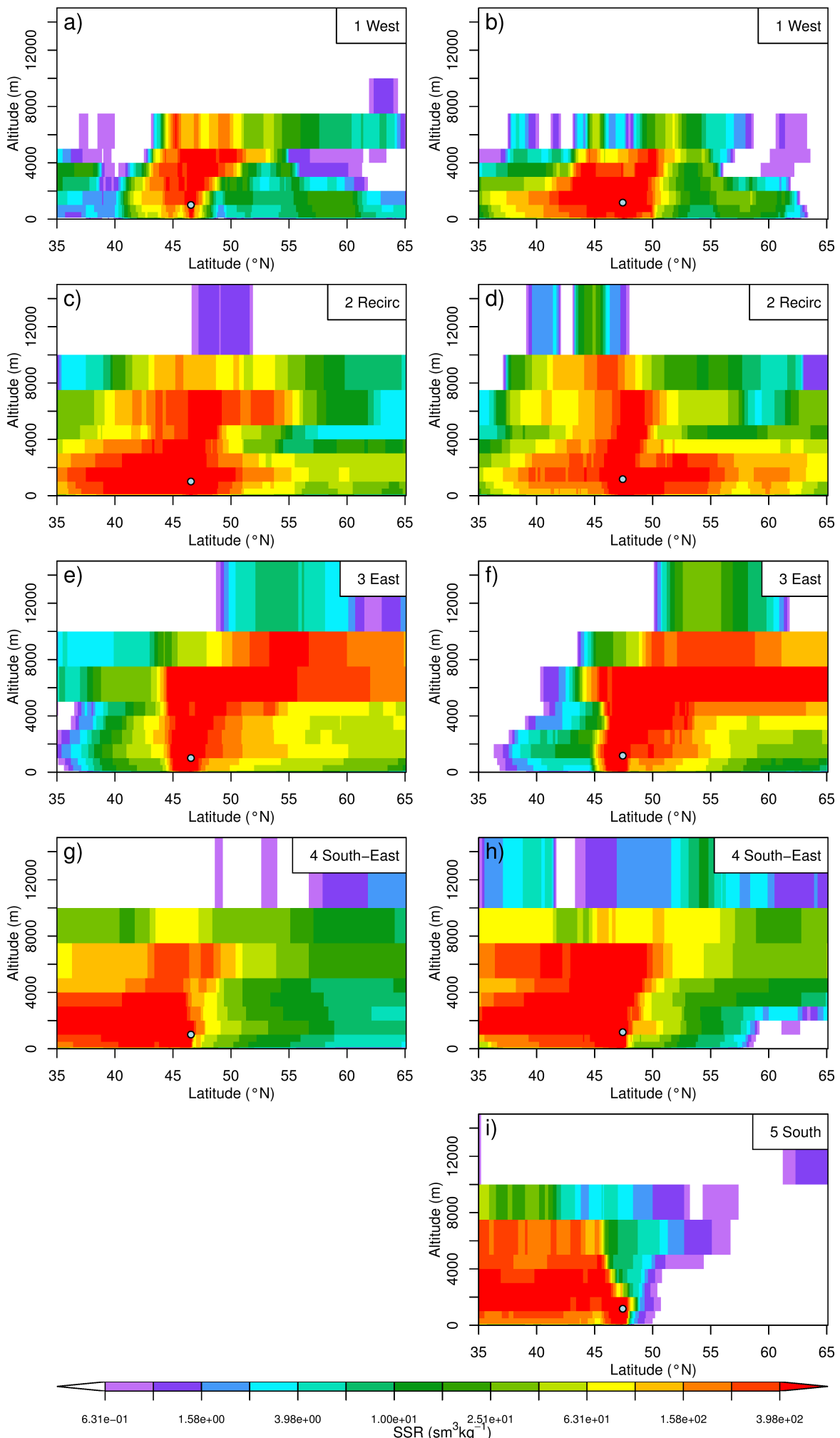

Figure 5. Cluster average latitude-altitude distribution of source receptor relationships (SRRs) for (a, c, e, g) JFJ and (b, d, f, h, i) ZSF. The sampling locations are given by a light blue circle. 

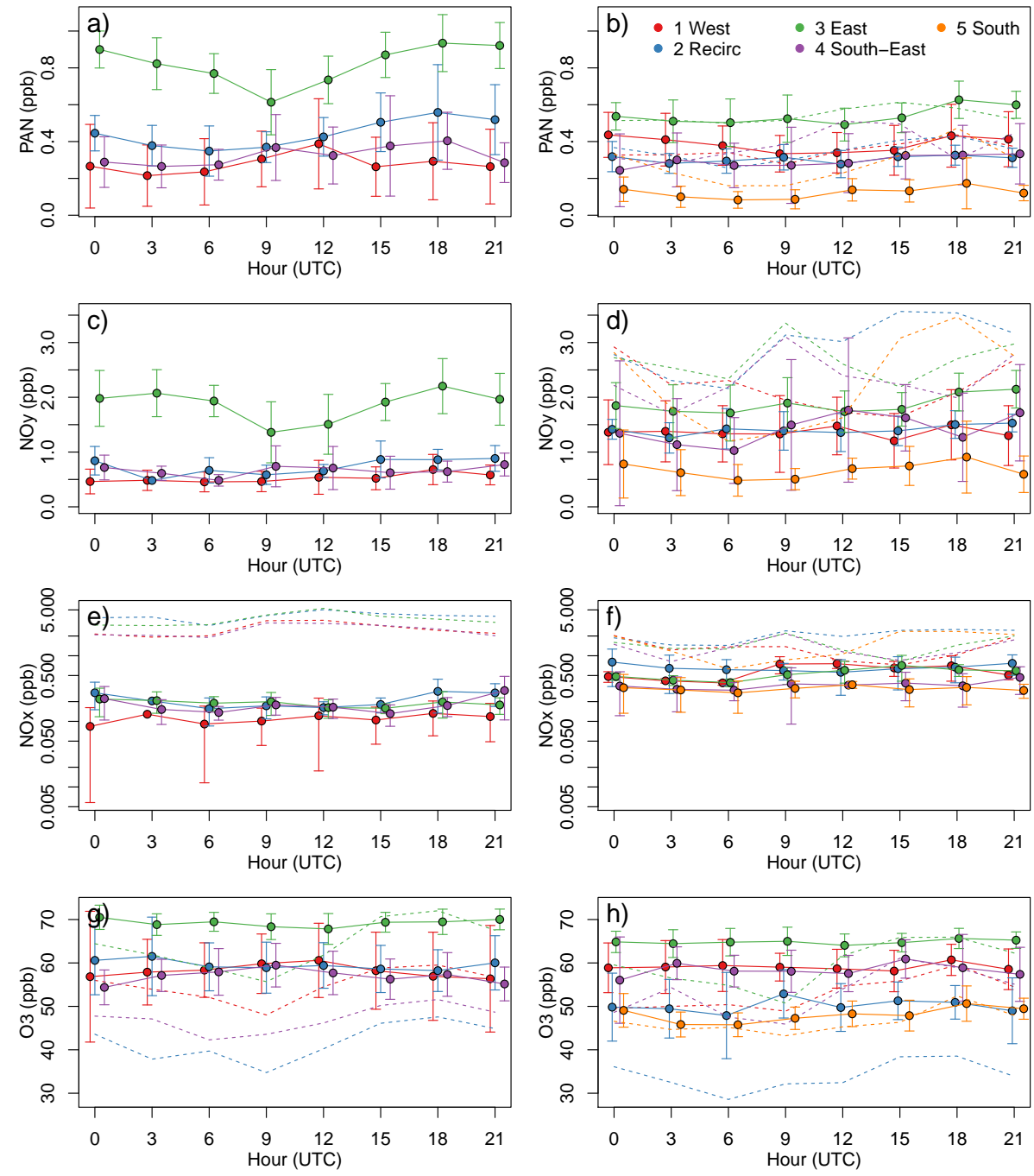

Figure 6. Average diurnal cycles of (a, b) PAN, (c, d) $\mathrm{NO}_{\mathrm{y}}$, (e, f) $\mathrm{NO}_{\mathrm{x}}$ and $(\mathbf{g}, \mathbf{h}) \mathrm{O}_{3}$ split by a transport cluster as indicated by the different colours (see definition in $\mathbf{b}$ ), which represent the same clusters as in Fig. 3. The solid lines and error bars represent the high Alpine measurements at (a, $\mathbf{c}, \mathbf{e}, \mathbf{g}) \mathrm{JFJ}$ and $(\mathbf{b}, \mathbf{d}, \mathbf{f}, \mathbf{h}) \mathrm{ZSF}$. The dotted lines give the average diurnal cycle as observed at the reference PBL sites: average of RIG and CHA for JFJ, and HPB for ZSF. The error bars represent expanded uncertainty (95\% confidence limits) of the 3-hourly cluster means. Note that a logarithmic $y$ axis was chosen for $\mathrm{NO}_{\mathrm{x}}$. The time stamp of the 3-hourly aggregates corresponds to the end of the aggregation interval. For better visibility values for different clusters were slightly shifted on the $x$ axis, but the all refer to the times given on the axis.

the receptor will then result in correlation between $\mathrm{CO}$ and PAN spanning the range between the two end points of background conditions and pollution plume. The stronger the correlation the closer this simplified view actually matches reality, while weak correlations may indicate both: minor PAN production and/or ill-defined pollution plumes. In this study we analysed correlations for well-defined transport regimes and in a relatively short period of time. Hence, the background for each transport regime is thought to be relatively constant and correlations should be robust. The steeper the slope between PAN and CO the more efficient PAN was produced in the original plume. Similarly, $\mathrm{PAN}-\mathrm{O}_{3}$ slopes can be an indicator of how efficient PAN was produced in com- parison to $\mathrm{O}_{3}$ production. It can be expected that PAN production is more efficient in very polluted air masses (or fresh emission plume) and becomes less efficient for less polluted air masses (or older plume) (Roberts et al., 1995).

Finally and to foster the interpretation in terms of vertical mixing and local photochemical production, cluster average afternoon (12:00 and 15:00 UTC) PBL heights and daytime (06:00, 09:00, 12:00, and 15:00 UTC) cloud cover maps for Central Europe were derived from ECMWF-IFS operational analysis and forecast data, the same as used for the transport simulations (Fig. 9). PBL heights were derived by applying a critical Richardson number criterion (Vogelezang and Holtslag, 1996). 

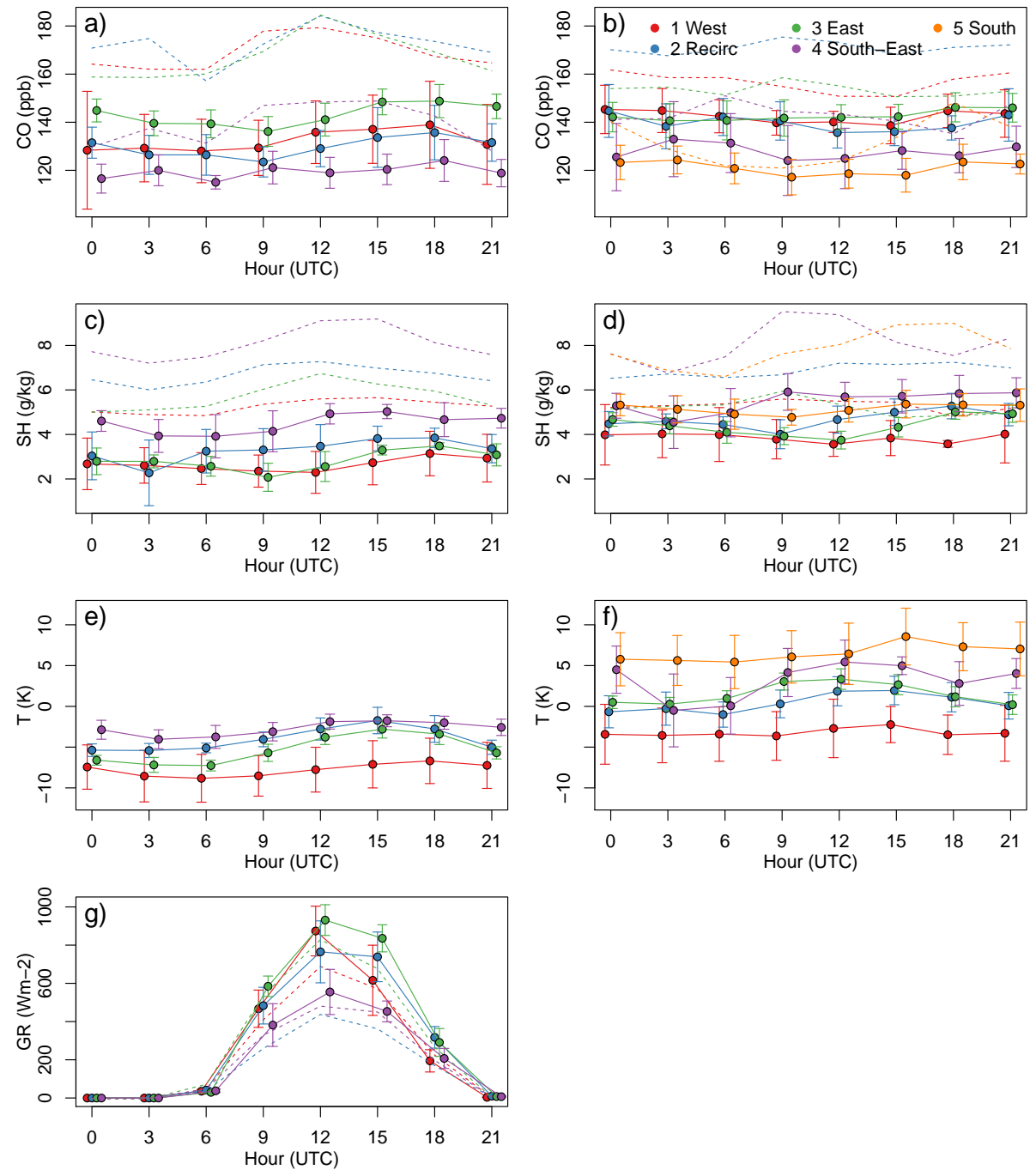

Figure 7. Same as Fig. 6, but for (a, b) CO, (c, d) specific humidity, (e, f) ambient temperature and (g) global radiation at (a, c, e, g) JFJ and $(\mathbf{b}, \mathbf{d}, \mathbf{f}) \mathrm{ZSF}$.

The individual transport clusters can be described as follows:

- Cluster 1 (westerly advection): the SRRs in this cluster indicate a cyclonic flow from the North Atlantic region passing over the Iberian Peninsula and France before reaching JFJ and ZSF (Figs. 4 and 5 and Figs. S1 and S2). Additional influence from the western Mediterranean was identified for ZSF. While in general, westerly advection with descending flow dominated this cluster, mainly representing air masses from lower tropospheric levels, sampled air masses had occasional PBL contact over France, Switzerland and, in the case of ZSF, southern Germany (Fig. 4, right panel). The influence of surface emissions was larger for ZSF than JFJ, as indicated by greater SRRs for the former. This category was experienced during an uninterrupted period from the beginning of May to 5 May. PAN concen- trations were relatively low, in the range between 0.2 and $0.5 \mathrm{ppb}$ at ZSF but dropped below this range at JFJ from 3 May onwards (Fig. 3). This coincides with a period of decreased $\mathrm{CO}$ and $\mathrm{O}_{3}$ at JFJ (see above). From the presented continental-scale SRRs the difference in transport patterns between JFJ and ZSF is not apparent. However, when looking at the SRRs for the larger Northern Hemisphere (see Figs. S1 and S2) it becomes clear that in the case of JFJ parts of the air masses summarised in this transport regime actually originated over the southern North Atlantic, were transported northward over the Atlantic and finally advected towards Europe. This partially tropical origin could explain the relatively low mole fractions of $\mathrm{CO}$ and $\mathrm{O}_{3}$ as observed at JFJ during the second half of this transport regime. Similar transport events towards JFJ were previously reported by Bond et al. (2011), who documented the influence 

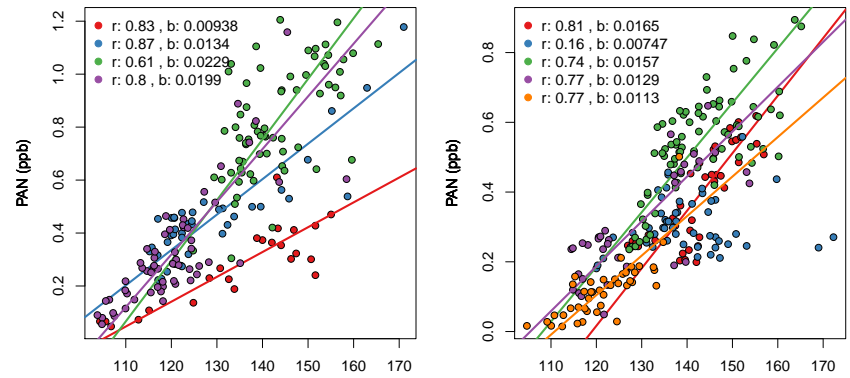

$\mathrm{CO}(\mathrm{ppb})$
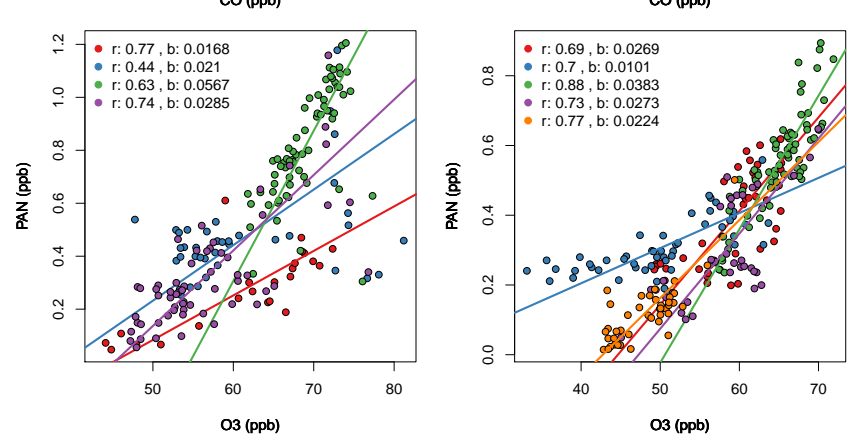

Figure 8. Scatter plots of observed mole fractions of PAN vs. carbon monoxide (top) and PAN vs. ozone (bottom) for Jungfraujoch (JFK, left) and Zugspitze (ZSF, right). Regression lines (obtained using weighted total least-square regression, see text) are only shown if significant correlations between the trace gases exist. The colours represent the correlations within the individual transport clusters, see Fig. 3 and text.

of advection from low northern latitudes on molecular hydrogen, methane and CO. Primary pollutant concentrations in this cluster were generally low. Occasionally high $\mathrm{O}_{3}$ mixing ratios may indicate the influence of higher altitude air masses. At both sites, no pronounced diurnal cycle was observed for $\mathrm{PAN}, \mathrm{NO}_{\mathrm{y}}$ or $\mathrm{NO}_{\mathrm{x}}$, while a weak afternoon increase in $\mathrm{CO}$ and specific humidity could be seen for JFJ. $\mathrm{NO}_{\mathrm{x}}, \mathrm{CO}$ and specific humidity differences between the PBL and the high Alpine sites were larger for JFJ suggesting a larger degree of decoupling of the site from the PBL as in the case of ZSF (Figs. 6 and 7). According to model derived average afternoon PBL heights both sites were influenced by PBL air in the afternoon (Fig. 9). Cloud cover was rather large in the region that air masses passed prior to arrival at JFJ, indicating moderate photochemical turnover in these air masses. For ZSF air masses had a less direct transport path from the west and also showed surface contact in regions that were more cloud free (southwestern Germany, south-western France). These observations also agree with the estimated regression slopes of PAN to CO (Fig. 8) that were steeper for ZSF than JFJ indicating less efficient PAN production in the air mass that reached JFJ. Overall the PAN-CO slope exhibited moderate values in this cluster. In summary, the observed conditions were not favourable of regionalscale PAN production from recent emissions for JFJ, but indicated recent production for ZSF due to increased emission contact of the sampled air masses.

- Cluster 2 (Recirculating north-easterly/south-westerly advection): this flow regime comprises air masses that mainly arrived from north-easterly directions with additional surface influence south-west of the sites (Figs. 4 and 5). This is not the consequence of overlaying two separate transport regimes at different times, but is also characteristic for most of the individual SSRs during this period. The core of the backward plume typically moved slowly south-westward before taking a northeasterly and ascending path. Finally, part of the plume was recirculated westwards at higher altitudes and detrained into the PBL again, causing increased surface emission sensitivities west of the sites. The surface footprint for JFJ in the Fig. 4 indicates relatively large emission sensitivities over the western Alps and France, the easterly component is more pronounced for ZSF with strong sensitivities along the northern flank of the Alps in Austria and Bavaria. The regime occurred on 5 and 6 May and again between 18 and 25 May. This cluster showed considerable PBL contact in agreement with high water vapour content as observed at the sites. PAN mole fractions at both sites remained moderate for most of the category $(\sim 0.4$ and $0.3 \mathrm{ppb}$ for JFJ and ZSF, respectively). However, JFJ experienced a few hours of high PAN on 6 May which fell into this cluster and caused the late afternoon peak in the overall diurnal cycle for this cluster (Fig. 6). Average daytime cloud cover was relatively large in this category (Fig. 9) suggesting weak photochemical activity and, hence, little potential for regional-scale photochemical production of PAN from recent emissions. This is also supported by the insignificant correlations between PAN and $\mathrm{CO}$ as observed at ZSF and the relatively small PAN-CO slope at JFJ (Fig. 8). Again, the large PAN-CO correlation at JFJ results from the measurements on 6 May that were not typical for this cluster. Furthermore, trace gas observations on 23 May at JFJ suggested a short phase of stratospheric influence (high $\mathrm{O}_{3}$, low $\mathrm{CO}$ and humidity, see Fig. 3), which was not encountered at ZSF.This is supported by the dispersion calculation that indicates air originating from the tropopause region over northwestern France (see Fig. S3, top left), but the surface sensitivity map showed a rather indifferent distribution (Fig. S3, top right). This short event of stratospheric influence was not picked up by the cluster analysis because the latter focuses on the geographical distribution of surface sensitivities. Another reason, why the event was not placed in a separate category by the clustering was our aim to limit the number of transport clusters for a straightforward interpretation. With an increasing 

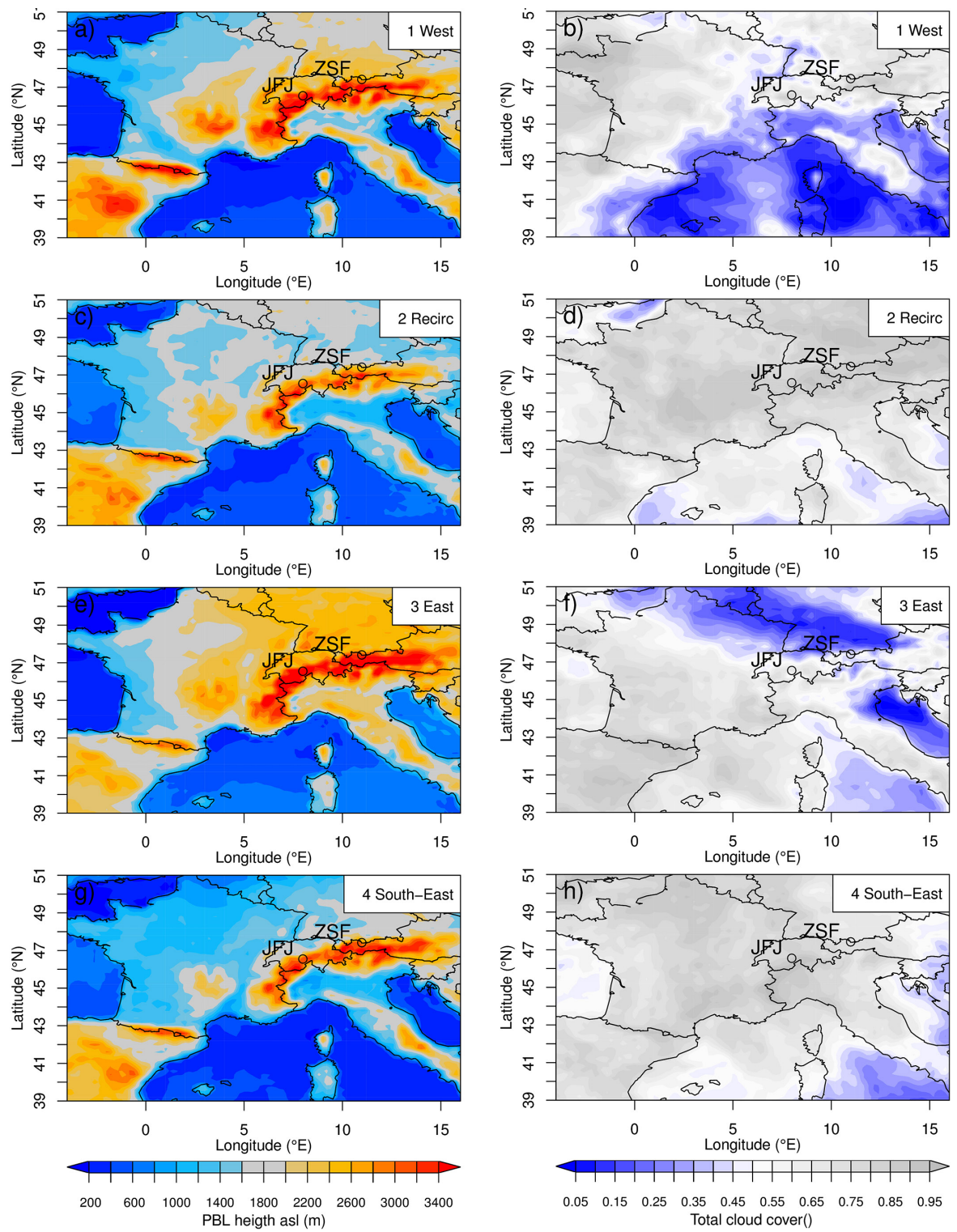

Figure 9. Cluster average for $(\mathbf{a}, \mathbf{c}, \mathbf{e}, \mathbf{g})$ afternoon PBL height and $(\mathbf{b}, \mathbf{d}, \mathbf{f}, \mathbf{h})$ daytime total cloud cover fraction for the transport clusters as derived for JFJ. Afternoon PBL heights were calculated from ECMWF-IFS operational analysis and forecast fields at 12:00 and 15:00 UTC using a critical Richardson number criterion. Daytime total cloud cover was taken from the same ECMWF fields at (06:00, 09:00, 12:00, and 15:00 UTC).

number of categories, eventually the event would have been placed into its own category. Due to the shortness of the event we did not manually exclude it from the analysis.

- Cluster 3 (easterly advection): the SRRs in this cluster describe typical anticyclonic conditions with easterly to north-easterly advection and descending air masses. In addition, a southerly component close to the sites caused enhanced surface emission sensitivities in northern Italy and Switzerland for JFJ and Austria and to a smaller degree northern Italy for ZSF (Fig. 4). From
Fig. 5 it can be seen that during this period freetropospheric air masses descended in the anticyclone. However, air masses had contact with the PBL shortly before reaching the sites, as can be seen by the relatively focused surface SRRs (Fig. 4). By far the highest pollutant concentrations were observed in this cluster including maxima for PAN, $\mathrm{NO}_{\mathrm{y}}, \mathrm{NO}_{\mathrm{z}}, \mathrm{O}_{3}$ and $\mathrm{CO}$. The descending airflow in this category may suggest that the observed PAN was mainly of free-tropospheric origin. However, the following considerations against this hypothesis can be made. First, next to PAN also $\mathrm{CO}$ was elevated at both sites. While part of this $\mathrm{CO}$ 
may have been produced in the free troposphere from VOC and $\mathrm{CH}_{4}$ degradation, it seems more likely that it stems from direct surface emissions. Second, the decreased cloud cover over southern Germany and Eastern Europe (Fig. 9) favoured PBL photochemical production of PAN from fresh emissions in the PBL. Third, PAN levels at ZSF were as high as at the nearby PBL site HPB (Fig. 6). No diurnal cycle of PAN was observed at ZSF and the model estimated daytime PBL top was well above the sites altitude (Fig. 9), both suggesting that ZSF was completely within the daytime PBL and remained within a residual layer during the night. This is in contrast to the usually intermittent PBL influence observed at high altitude sites, caused by the injection of PBL air into the FT over Alpine terrain (Henne et al., 2004; De Wekker et al., 2004). If ZSF is completely situated within the PBL or residual layer, it will be likely that PAN was recently produced from fresh emission than from increases in hemispheric background levels. Fourth, PAN was larger at JFJ as compared to ZSF and showed a diurnal cycle typical of daytime injections of PBL air (Fig. 6). This is also supported by a similar diurnal cycle in $\mathrm{CO}$ and specific humidity. No systematic diurnal cycle was observed for $\mathrm{O}_{3}$ at JFJ, most probably due to the fact that afternoon $\mathrm{O}_{3}$ mole fractions were similar in the PBL as indicated by the observations at CHA and RIG (where night-time values were decreased due to surface deposition, see Fig. 6). PAN production in such PBL injections can be very efficient since large amounts of fresh precursors $\left(\mathrm{NO}_{\mathrm{x}}\right.$ and peroxyacetyl radicals) are available and the air mass is adiabatically cooled during the injection, moving the $\mathrm{NO}_{2}-\mathrm{PAN}$ balance towards PAN (Henne et al., 2005a). The average PAN-CO slope at JFJ was 0.023 as compared with 0.016 at ZSF (see Fig. 8), suggesting that additional, rapid PAN production took place when PBL air was transported to JFJ. The relatively small correlation coefficient at JFJ (0.56) as compared to ZSF (0.75) may indicate various levels of PAN production efficiencies in different PBL injections. At night-time PAN levels at JFJ were comparable to those at ZSF or even fell under those at ZSF (8 and 9 May, see Fig. 3). $\mathrm{NO}_{\mathrm{y}}$ levels were comparable for both sites. However, the PAN / $\mathrm{NO}_{\mathrm{y}}$ ratio was larger at JFJ, which again indicates fresh PAN production, since no precipitation occurred in this regime, which could have washed out $\mathrm{NO}_{\mathrm{y}}$ (remember that the water soluble $\mathrm{HNO}_{3}$ is an important species in the class of $\mathrm{NO}_{\mathrm{y}}$ ). Precursor levels in the PBL adjacent to JFJ were actually larger $\left(\mathrm{NO}_{\mathrm{x}} 3-5 \mathrm{ppb}\right)$ as compared with $\mathrm{HPB}(<2 \mathrm{ppb})$. For JFJ large emission sensitivities over the western Po Valley were estimated. The western Po Valley including the metropolitan area of Milan comprises large anthropogenic emissions of $\mathrm{NO}_{\mathrm{x}}$ and VOCs (e.g. Prévôt et al., 1997) and weak ventilation conditions favour the ac- cumulation of pollutants. In addition, large amounts of biogenic VOC emissions occur within the Alpine region and may deliver the amount of peroxyacetyl radicals required for strong PAN production.

In summary, these observations point towards a regional-scale production of PAN in the PBL, which may further be enhanced when PBL air masses are lifted into the lower FT, where they were sampled at JFJ.

- Cluster 4 (south-easterly advection): Fig. 4 shows that air masses combined in this cluster had only weak surface contact, mainly close to the sites within the Alps and over Italy and the adjacent parts of the Mediterranean. The respective air masses remained within the lower FT north of $30^{\circ} \mathrm{N}$ prior to arrival at the sites (see Figs. S1 and S2). This flow pattern occurred during two episodes in May 2008, namely 15-18 May and 26-31 May. For ZSF two transport clusters were present during these periods, the second one is described below. The current cluster showed low PAN mean concentrations of $0.2-0.4 \mathrm{ppb}$ and also experienced other, rather low, trace gas concentrations $\left(\mathrm{NO}_{\mathrm{x}}, \mathrm{NO}_{\mathrm{y}}, \mathrm{CO}\right)$. No diurnal cycle in any of the trace species was observed at either site, compared to close-by PBL sites (Fig. 6). Hence, the influence from recent emissions on these air masses was considered small. Recent photochemical processing in these air masses was probably low due to relatively large cloud cover over the Alps and northern Italy. The PAN-CO slope at JFJ was almost as large as for cluster 3 . However, this was mainly caused by the attribution of high PAN levels on 15 May to this cluster. This day was the last of the high PAN episode and probably better related to cluster 3 than to the current transport cluster. Without the data from 15 May the correlation coefficient and slope considerably decreased. Similar arguments can be made for ZSF, where PAN mixing ratios were still large on 15 and 16 May, which were assigned to the current cluster, but probably should have been assigned to the high PAN cluster (3).

- Cluster 5 (southerly advection; ZSF only): this SRR describes the transport path from the south, with moderate SRRs over the Mediterranean and Italy and additional boundary layer contact in the Alpine region. While there are large $\mathrm{NO}_{\mathrm{x}}$ sources especially in the western part of the Po Valley, a close look at the surface sensitivities (Fig. 4i) reveals that these were most likely not intercepted by the air masses in this cluster, which showed larger emission sensitivities only in the Alpine area north of the Po Valley and again south of the Po Valley. In line with the transport simulations, PAN, $\mathrm{NO}_{\mathrm{y}}$ and $\mathrm{CO}$ mixing ratios were the lowest in this cluster. Due to the southern, low-tropospheric origin of the air masses, these were relatively warm and moist as compared to the other transport clusters. While the 
correlationbetween PAN and CO was the strongest of all clusters, the regression slope was the smallest (Fig. 8), indicating inefficient PAN production, most likely due to the lack of available $\mathrm{NO}_{2}$ and photochemical production (cloudy conditions during transport; see Fig. 9h).

\subsubsection{Correlation between PAN and ozone}

Figure 8 (bottom) shows PAN vs. ozone correlations for the individual clusters. Correlations between PAN and $\mathrm{O}_{3}$ mole fractions contain valuable information of the production of the two photo-oxidants integrated over the time since the release of the primary pollutant. Very large slopes up to 0.1 were reported from the Los Angeles basin for fall 1980 (Grosjean, 1983) representing highly polluted air masses, particularly very high $\mathrm{NO}_{\mathrm{x}}$ concentrations. The relation between the slopes of PAN vs. $\mathrm{O}_{3}$ with air pollution loadings was demonstrated from daytime measurements during summer 1987 at the rural site Niwot Ridge, CO, USA (Ridley et al., 1990). The PAN-O 3 slope was 0.048 for polluted air (up-slope flow from easterly directions), but was 5 times smaller for westerly advection of less polluted air. Roberts et al. (1995) found slopes around 0.0242 in campaign measurements from rural sites in eastern US in summer 1988, which also can be compared with the slopes of our study though the physical conditions of our Alpine mountain sites are not directly comparable with those of the summer campaigns in US.

In our study the highest slopes were found in cluster 3 (Easterly advection) (see Fig. 8). At JFJ PAN vs. $\mathrm{O}_{3}$, the slope was 0.057 supporting our result that PAN was enhanced because of recent contact with polluted PBL air (Fig. 6). At ZSF the slope in the same cluster was lower (0.038), indicating less favourable PAN production condition than for JFJ. The lowest PAN-O 3 slopes were observed for cluster 1 (westerly advection) at JFJ (0.017) and cluster 2 (recirculating north-easterly-south-westerly advection) at ZSF $(<0.017)$. In these air masses contact with recent polluted planetary boundary layer was found to be small, also resulting in low $\mathrm{NO}_{\mathrm{x}}$ mole fraction.

\subsubsection{Representativeness of spring 2008}

In order to further explore the representativeness of the weather conditions encountered in spring 2008, we compared the transport clusters obtained in our study with a long-term weather type classification. The Alpine Weather Statistic (AWS) is a weather classification that was developed to characterise the weather situation at a given time over the Swiss domain (MeteoSwiss, 1985; Wanner et al., 1998). The AWS was previously used to analyse PBL transport to JFJ (Henne et al., 2005b). The AWS types convective-indifferent and convective-anticyclonic were identified as weather types for which PBL transport to JFJ was likely during the afternoon of spring and summer months. Our JFJ cluster 3 largely corresponds with the AWS weather sub-types convective-anticyclonic flat pressure and convective-indifferent easterly advection. The frequency of these two weather types for the years 2001 to 2010 and the months April and May was relatively large in 2008 (> 13 days) but comparable to other years (2007: 15 days; Fig. S4a). When looking at the frequency of all convective-anticyclonic and convective-indifferent weather types, which are likely to allow PBL transport to JFJ, the frequency in 2008 (30 days) was only slightly larger than the average frequency for all years (27 days; Fig. S4b). Hence, our conclusion on the representativeness of our 2008 case study is twofold. On the one hand, the occurrence of strong PBL influence during easterly flow in May 2008 was exceptional in its persistence and continuation for about 10 days. On the other hand, the frequency of weather types with likely PBL transport towards JFJ was not larger in spring 2008 than in other years. Therefore, we are convinced that our findings concerning the origin of the pronounced springtime PAN maximum at high Alpine sites are not restricted to the analysed year but can be interpreted in a more general way.

\section{Conclusions}

In agreement with previous studies, PAN measurements from ZSF and JFJ showed a pronounced seasonal cycle with maximum mole fractions in late spring. This indicates that the spring maximum of PAN in background air masses as observed at other northern hemispheric sites is also a typical phenomenon at high Alpine sites. The origin of the springtime maximum at the two Alpine sites was evaluated in more detail for May 2008 when PAN levels at JFJ were especially large. Different transport regimes towards the sites were distinguished using a clustering method on backward dispersion simulations. These show that air masses in May 2008 had recent PBL contact in different parts of Europe before reaching the measurement stations at JFJ and ZSF. At both sites, the highest PAN concentrations of May 2008 were connected with descending air masses in an anticyclonic flow (cluster 3). However, these air masses experienced pronounced contact with the PBL under photochemically favourable (cloud-free) conditions, prior to the arrival at the sites. A comparison with nearby PBL sites reveals that the ZSF observatory was situated within the daytime PBL, while JFJ was influenced by PBL injections during this period. PAN levels were considerably lower during all other flow regimes also for those less influenced by recent PBL contact. Therefore, we conclude from our study that under the conditions as sampled at two high Alpine European sites, PAN spring maxima are mainly caused by the following factors: (1) high pressure conditions lead to an accumulation of trace gases in the PBL and vertical transport from the PBL becomes important for transporting the pollutants to the sites, (2) solar irradiance is already large in May which enhances the photochemistry during cloud-free conditions 
as encountered during the anticyclonic transport regime and (3) temperatures are still relatively low in the lower free troposphere preventing thermal decomposition of PAN which becomes more important in summer.

The analysis of the high spring PAN mixing ratios at these Alpine sites clearly suggests that the spring maximum is primarily caused by PAN production in and export from the regional PBL. The highest PAN observations during May 2008 were not connected with free-tropospheric conditions, but with PBL air masses. These results agree well with those of Pandey Deolal et al. (2013) which, based on hemispheric-scale backward trajectories, indicate that those air masses which had surface contact in the European boundary layer were associated with the largest $\mathrm{PAN}$ and $\mathrm{NO}_{\mathrm{y}}$ mixing ratios in spring and are attributable to European boundary layer sources and not inter-continental transport or freetropospheric production. However, free-tropospheric background and inter-continental transport also make a significant contribution, as PAN mole fraction in such air masses without recent contact with European PBL were found to be around $0.20-0.25 \mathrm{ppb}$ (see Pandey Deolal et al., 2013) which is in rather good agreement with an estimate from the present analysis; averaged PAN concentrations from cluster 1 (most typical for long-range transport) were 0.278 , whereas PAN concentrations of cluster 3 most relevant for European PBL advection were around $0.8 \mathrm{ppb}$. The presented analysis is restricted to one month; however, analysis of respective synoptic condition according to Alpine weather statistics shows that this and similar weather conditions are common for European spring conditions, and therefore we may conclude that the appointed mechanism for the PAN spring maxima is typical also for other years.

\section{The Supplement related to this article is available online at doi:10.5194/acp-14-12553-2014-supplement.}

Acknowledgements. We thank the Swiss National Foundation (SNF) for providing funding of projects no. 200020-117626 and no. 206021_128754 to carry out this research. We also express our gratitude towards international foundation for high Alpine research stations Jungfraujoch and Gornergrat (HFSJG) for providing access to Jungfraujoch facilities and respective custodians for their support. We are thankful to NABEL for their data, which is operated by Empa in collaboration with the Swiss Federal Office for the Environment. We also thank MeteoSwiss for provision of meteorological data from Jungfraujoch.

Edited by: A. Pozzer

\section{References}

Balzani Lööv, J. M., Henne, S., Legreid, G., Staehelin, J., Reimann, S., Prévôt, A. S. H., Steinbacher, M., and Vollmer, M. K.: Estimation of background concentrations of trace gases at the Swiss Alpine site Jungfraujoch (3580 m a.s.1.), J. Geophys. Res., 113, D22305, doi:10.1029/2007JD009751, 2008.

Bond, S. W., Vollmer, M. K., Steinbacher, M., Henne, S., and Reimann, S.: Atmospheric molecular hydrogen (H-2): observations at the high-altitude site Jungfraujoch, Switzerland, Tellus B, 63, 64-76, doi:10.1111/j.1600-0889.2010.00509.x, 2011.

Bottenheim, J. W., Sirois, A., Brice, K. A., and Gallant, A. J.: Five years of continuous observations of PAN and ozone at a rural location in eastern Canada, J. Geophys. Res., 99, 5333-5352, doi:10.1029/93JD02716, 1994.

Brunner, D., Henne, S., Keller, C. A., Reimann, S., Vollmer, M. K., O'Doherty, S., and Maione, M.: An extended Kalman-filter for regional scale inverse emission estimation, Atmos. Chem. Phys., 12, 3455-3478, doi:10.5194/acp-12-3455-2012, 2012.

Cooper, O. R., Moody, J. L., Parrish, D. D., Trainer, M., Ryerson, T. B., Holloway, J. S., Hübler, G., Fehsenfeld, F. C., Oltmans, S. J., and Evans, M. J.: Trace gas signatures of the airstreams within North Atlantic cyclones: Case studies from the North Atlantic Regional Experiment (NARE '97) aircraft intensive, J. Geophys Res., 106, 5437-5456, 2001.

Cooper, O., Forster, C, Parrish, D., Dunlea, E., Hübler, G., Fehsenfeld, F., Holloway, J., Oltmans, S., Johnson, B., Wimmers, A., and Horowitz, L.: A Case Study of Trans-Pacific warm Conveyor belt Transport: The Influence of Merging Airstreams on Trace Gas Import to North America, J. Geophys. Res., 109, D23S08, doi:10.1029/2003JD003624, 2004.

Cooper, O. R., Parrish, D. D., Stohl, A., Trainer, M., Nedelec, P., Thouret, V., Cammas, J. P., Oltmans, S. J., Johnson, B. J., Tarasick, D., Leblanc, T., McDermid, I. S., Jaffe, D., Gao, R., Stith, J., Ryerson, T., Aikin, K., Campos, T., Weinheimer, A., and Avery, M. A.: Increasing springtime ozone mixing ratios in the free troposphere over western North America, Nature, 463, 344-348, doi:10.1038/nature08708, 2010.

De Wekker, S. F. J., Steyn, D. G., and Nyeki, S.: A comparison of aerosol layer- and convective boundary layer structure over a mountain range during STAAARTE '97, Bound. Lay. Meteorol., 113, 249-271, 2004.

Empa and FOEN: Technischer Bericht zum Nationalen Beobachtungsnetz für Luftfremdstoffe (NABEL) 2013, Empa, Dübendorf, Switzerland, available at: http://www.empa.ch/plugin/ template/empa/*/139851 (last access: 18 November 2014), 226, 2013.

Fenneteaux, I., Colin, P., Etienne, A., Boudries, H., Dutot, A. L., Perros, P. E., and Toupance, G.: Influence of Continental Sources on Oceanic Air Composition at the Eastern Edge of the North Atlantic Ocean, TOR 1992-1995, J. Atmos. Chem., 32, 233-280, doi:10.1023/A:1006140223711, 1999.

Fiore, A. M., Dentener, F. J., Wild, O., Cuvelier, C., Schultz, M. G., Hess, P., Textor, C., Schulz, M., Doherty, R. M., Horowitz, L. W., MacKenzie, I. A., Sanderson, M. G., Shindell, D. T., Stevenson, D. S., Szopa, S., Van Dingenen, R., Zeng, G., Atherton, C., Bergmann, D., Bey, I., Carmichael, G., Collins, W. J., Duncan, B. N., Faluvegi, G., Folberth, G., Gauss, M., Gong, S., Hauglustaine, D., Holloway, T., Isaksen, I. S. A., Jacob, D. J., Jonson, J. E., Kaminski, J. W., Keating, T. J., Lupu, A., Marmer, 
E., Montanaro, V., Park, R. J., Pitari, G., Pringle, K. J., Pyle, J. A., Schroeder, S., Vivanco, M. G., Wind, P., Wojcik, G., Wu, S., and Zuber, A.: Multimodel estimates of intercontinental sourcereceptor relationships for ozone pollution, J. Geophys. Res., 114, D04301, doi:10.1029/2008JD010816, 2009.

Fischer, E. V., Jaffe, D. A., Reidmiller, D. R., and Jaeglé, L.: Meteorological controls on observed peroxyacetyl nitrate at Mount Bachelor during the spring of 2008, J. Geophys. Res., 115, D03302, doi:10.1029/2009JD012776, 2010.

Fischer, E. V., Jacob, D. J., Yantosca, R. M., Sulprizio, M. P., Millet, D. B., Mao, J., Paulot, F., Singh, H. B., Roiger, A., Ries, L., Talbot, R.W., Dzepina, K., and Pandey Deolal, S.: Atmospheric peroxyacetyl nitrate (PAN): a global budget and source attribution, Atmos. Chem. Phys., 14, 2679-2698, doi:10.5194/acp-142679-2014, 2014.

Gantner, L., Hornsteiner, M., Egger, J., and Hartjenstein, G.: The diurnal circulation of Zugspitzplatt: observations and modeling, Meteorol. Z., 12, 95-102, doi:10.1127/0941-2948/2003/00120095, 2003.

Gilge, S., Plass-Duelmer, C., Fricke, W., Kaiser, A., Ries, L., Buchmann, B., and Steinbacher, M.: Ozone, carbon monoxide and nitrogen oxides time series at four alpine GAW mountain stations in central Europe, Atmos. Chem. Phys., 10, 12295-12316, doi:10.5194/acp-10-12295-2010, 2010.

Grosjean, D.: Distribution of atmospheric nitrogenous pollutants at a Los Angeles area smog receptor site, Environ. Sci. Technol., 17, 13-19, doi:10.1021/es00107a006, 1983.

Hamburger, T., McMeeking, G., Minikin, A., Birmili, W., Dall'Osto, M., O’Dowd, C., Flentje, H., Henzing, B., Junninen, H., Kristensson, A., de Leeuw, G., Stohl, A., Burkhart, J. F., Coe, H., Krejci, R., and Petzold, A.: Overview of the synoptic and pollution situation over Europe during the EUCAARI-LONGREX field campaign, Atmos. Chem. Phys., 11, 1065-1082, doi:10.5194/acp-11-1065-2011, 2011.

Henne, S., Furger, M., Nyeki, S., Steinbacher, M., Neininger, B., de Wekker, S. F. J., Dommen, J., Spichtinger, N., Stohl, A., and Prévôt, A. S. H.: Quantification of topographic venting of boundary layer air to the free troposphere, Atmos. Chem. Phys., 4, 497-509, doi:10.5194/acp-4-497-2004, 2004.

Henne, S., Dommen, J., Neininger, B., Reimann, S., Staehelin, J., and Prévôt, A. S. H.: Influence of mountain venting in the Alps on the ozone chemistry of the lower free troposphere and the European pollution export, J. Geophys. Res., 110, D22307, doi:10.1029/2005JD005936, 2005a.

Henne, S., Furger, M., and Prévôt, A. S. H.: Climatology of mountain venting induced moisture layers in the lee of the Alps, J. Appl. Meteorol., 44, 620-633, 2005b.

Henne, S., Brunner, D., Folini, D., Solberg, S., Klausen, J., and Buchmann, B.: Assessment of parameters describing representativeness of air quality in-situ measurement sites, Atmos. Chem. Phys., 10, 3561-3581, doi:10.5194/acp-10-3561-2010, 2010.

Hirdman, D., Sodemann, H., Eckhardt, S., Burkhart, J. F., Jefferson, A., Mefford, T., Quinn, P. K., Sharma, S., Ström, J., and Stohl, A.: Source identification of short-lived air pollutants in the Arctic using statistical analysis of measurement data and particle dispersion model output, Atmos. Chem. Phys., 10, 669-693, doi:10.5194/acp-10-669-2010, 2010.

Kaiser, A., Scheifinger, H., Spangl, W., Weiss, A., Gilge, S., Fricke, W., Ries, L., Cemas, D., and Jesenovec, B.: Transport of nitrogen oxides, carbon monoxide and ozone to the Alpine Global Atmosphere Watch stations Jungfraujoch (Switzerland), Zugspitze and Hohenpeissenberg (Germany), Sonnblick (Austria) and Mt. Krvavec (Slovenia), Atmos. Environ., 41, 9273-9287, doi:10.1016/j.atmosenv.2007.09.027, 2007.

Kaufman, L. and Rousseeuw, P. J.: Finding Groups in Data. An Introduction to Cluster Analysis, John Wiley and Sons, New York, 342 pp., 1990.

Keller, C. A., Brunner, D., Henne, S., Vollmer, M. K., O’Doherty, S., and Reimann, S.: Evidence for under-reported western European emissions of the potent greenhouse gas HFC-23, Geophys. Res. Lett., 38, L15808, doi:10.1029/2011GL047976, 2011.

Keller, C. A., Hill, M., Vollmer, M. K., Henne, S., Brunner, D., Reimann, S., O'Doherty, S., Arduini, J., Maione, M., Ferenczi, Z., Haszpra, L., Manning, A. J., and Peter, T.: European Emissions of Halogenated Greenhouse Gases Inferred from Atmospheric Measurements, Environ. Sci. Technol., 46, 217-225, doi:10.1021/es202453j, 2012.

Krystek, M. and Anton, M.: A weighted total least-squares algorithm for fitting a straight line, Meas. Sci. Technol., 18, 3438-3442, 2007.

MeteoSwiss: Alpenwetterstatistik Witterungskalender, Beschreibung der einzelnen Parameter, MeteoSwiss, Zürich, Switzerland, 1985.

Monks, P. S.: A review of the observations and origins of the spring ozone maximum, Atmos. Environ., 34, 3545-3561, 2000.

Moxim, W. J., Levy, H., and Kasibhatla, P. S.: Simulated global tropospheric PAN: Its transport and impact on $\mathrm{NO}_{\mathrm{x}}, \mathrm{J}$. Geophys. Res., 101, 12621-12638, 1996.

Nielsen, T., Samuelsson, U., Grennfelt, P., and Thomsen, E. L.: Peroxyacetyl Nitrate in Long -Range Transported Polluted Air, Nature, 293, 553-555, 1981.

Ordóñez, C., Elguindi, N., Stein, O., Huijnen, V., Flemming, J., Inness, A., Flentje, H., Katragkou, E., Moinat, P., Peuch, V.-H., Segers, A., Thouret, V., Athier, G., van Weele, M., Zerefos, C. S., Cammas, J.-P., and Schultz, M. G.: Global model simulations of air pollution during the 2003 European heat wave, Atmos. Chem. Phys., 10, 789-815, doi:10.5194/acp-10-789-2010, 2010.

Pandey Deolal, S., Brunner, D., Steinbacher, M., Weers, U., and Staehelin, J.: Long-term in situ measurements of $\mathrm{NO}_{\mathrm{x}}$ and $\mathrm{NO}_{\mathrm{y}}$ at Jungfraujoch 1998-2009: time series analysis and evaluation, Atmos. Chem. Phys., 12, 2551-2566, doi:10.5194/acp-12-25512012, 2012.

Pandey Deolal, S., Staehelin, J., Brunner, D., Cui, J., Steinbacher, M., Zellweger, C., Henne, S., and Vollmer, M. K.: Transport of PAN and $\mathrm{NO}_{\mathrm{y}}$ from different source regions to the Swiss high alpine site Jungfraujoch, Atmos. Environ., 64, 103-115, doi:10.1016/j.atmosenv.2012.08.021, 2013.

Parker, A. E., Monks, P. S., Wyche, K. P., Balzani-Lööv, J. M., Staehelin, J., Reimann, S., Legreid, G., Vollmer, M. K., and Steinbacher, M.: Peroxy radicals in the summer free troposphere: seasonality and potential for heterogeneous loss, Atmos. Chem. Phys., 9, 1989-2006, doi:10.5194/acp-9-1989-2009, 2009.

Penkett, S. A. and Brice, K. A.: The Spring Maximum in Photooxidants in the Northern-Hemisphere Troposphere, Nature, 319, 655-657, 1986.

Penkett, S. A., Blake, N. J., Lightman, P., Marsh, A. R. W., Anwyl, P., and Butcher, G.: The seasonal variation of nonmethane hydrocarbons in the free troposphere over the North Atlantic 
Ocean: Possible evidence for extensive reaction of hydrocarbons with the nitrate radical, J. Geophys. Res., 98, 2865-2885, doi:10.1029/92JD02162, 1993.

Prévôt, A. S. H., Staehelin, J., Kok, G. L., Schillawski, R. D., Neininger, B., Staffelbach, T., Neftel, A., Wernli, H., and Dommen, J.: The Milan photooxidant plume, J. Geophys. Res., 102, 23375-23388, 1997.

Rappenglück, B., Dasgupta, P. K., Leuchner, M., Li, Q., and Luke, W.: Formaldehyde and its relation to $\mathrm{CO}, \mathrm{PAN}$, and $\mathrm{SO}_{2}$ in the Houston-Galveston airshed, Atmos. Chem. Phys., 10, 2413-2424, doi:10.5194/acp-10-2413-2010, 2010.

Reiter, R., Sladkovic, R., and Kanter, H. J.: Concentration of trace gases in the lower troposphere, simultaneously recorded at neighboring mountain stations Part II: Ozone, Meteorol. Atmos. Phys., 37, 27-47, doi:10.1007/BF01047008, 1987.

Ridley, B. A., Shetter, J. D., Walega, J. G., Madronich, S., Elsworth, C. M., Grahek, F. E., Fehsenfeld, F. C., Norton, R. B., Parrish, D. D., Hübler, G., Buhr, M., Williams, E. J., Allwine, E. J., and Westberg, H. H.: The behavior of some organic nitrates at Boulder and Niwot Ridge, Colorado, J. Geophys. Res., 95, 13949-13961, doi:10.1029/JD095iD09p13949, 1990.

Ridley, B., Walega, J., Hübler, G., Montzka, D., Atlas, E., Hauglustaine, D., Grahek, F., Lind, J., Campos, T., Norton, R., Greenberg, J., Schauffler, S., Oltmans, S., and Whittlestone, S.: Measurements of $\mathrm{NO} x$ and PAN and estimates of $\mathrm{O}_{3}$ production over the seasons during Mauna Loa Observatory Photochemistry Experiment 2, J. Geophys. Res., 103, 8323-8339, doi:10.1029/98JD00075, 1998.

Roberts, J. M., Tanner, R. L., Newman, L., Bowersox, V. C., Bottenheim, J. W., Anlauf, K. G., Brice, K. A., Parrish, D. D., Fehsenfeld, F. C., Buhr, M. P., Meagher, J. F., and Bailey, E. M.: Relationships between PAN and ozone at sites in eastern North America, J. Geophys. Res., 100, 22821-22830, doi:10.1029/95JD01221, 1995.

Schrimpf, W., Linaerts, K., Müller, K. P., Koppmann, R., and Rudolph, J.: Peroxyacetyl Nitrate (PAN) Measurements During the POPCORN Campaign, J. Atmos. Chem., 31, 139-159, doi:10.1023/A:1006004031055, 1998.

Seibert, P. and Frank, A.: Source-receptor matrix calculation with a Lagrangian particle dispersion model in backward mode, Atmos. Chem. Phys., 4, 51-63, doi:10.5194/acp-4-51-2004, 2004.

Stohl, A., Forster, C., Frank, A., Seibert, P., and Wotawa, G.: Technical note: The Lagrangian particle dispersion model FLEXPART version 6.2, Atmos. Chem. Phys., 5, 2461-2474, doi:10.5194/acp-5-2461-2005, 2005.

Sturm, P., Tuzson, B., Henne, S., and Emmenegger, L.: Tracking isotopic signatures of $\mathrm{CO}_{2}$ at the high altitude site Jungfraujoch with laser spectroscopy: analytical improvements and representative results, Atmos. Meas. Tech., 6, 1659-1671, doi:10.5194/amt-6-1659-2013, 2013.

Tsalkani, N., Perros, P., Dutot, A. L., and Toupance, G.: Oneyear measurements of PAN in the Paris basin: Effect of meteorological parameters, Atmos. Environ. A-Gen., 25, 1941-1949, doi:10.1016/0960-1686(91)90275-C, 1991.
Tyndall, G. S., Apel, E., Williams, E., Flocke, F., Cohen, R. C., Gilge, S., Kim, S., Mills, G., O’Brien, J., Perring, A., Rappenglueck, B., Roberts, J., Schmitt, R., Swanson, A., Tanimoto, H., and Wooldridge, P. J.: PIE 2005: An intercomparison of measurement techniques for peroxynitrates (PANs), AGU Fall Meeting, San Francisco, CA, USA, 5-9 December 2005, 2005.

Vogelezang, D. H. P. and Holtslag, A. A. M.: Evaluation and model impacts of alternative boundary-layer height formulations, Bound. Lay. Meteorol., 81, 245-269, 1996.

Vollmer, M. K., Zhou, L., Greally, B. R., Henne, S., Yao, B., Reimann, S., Stordal, F., Cunnold, D. M., Zhang, X., Maione, M., Zhang, F., Huang, J., and Simmonds, P. G.: Emissions of ozone-depleting halocarbons from China, Geophys. Res. Lett., 36, L15823, doi:10.1029/2009GL038659, 2009.

Wanner, H., Salvisberg, E., Rickli, R., and Schuepp, M.: 50 years of Alpine Weather Statistics (AWS), Meteorol. Z., 7, 99-111, 1998.

Whalley, L. K., Lewis, A. C., McQuaid, J. B., Purvis, R. M., Lee, J. D., Stemmler, K., Zellweger, C., and Ridgeon, P.: Two highspeed, portable GC systems designed for the measurement of non-methane hydrocarbons and PAN: Results from the Jungfraujoch High Altitude Observatory, J. Environ. Monit., 6, 234-241, 2004.

Wunderli, S. and Gehrig, R.: Influence of temperature of formation and stability of surface PAN and ozone. A two year field study in Switzerland, Atmos. Environ. A-Gen., 25, 1599-1608, doi:10.1016/0960-1686(91)90018-3, 1991.

Zanis, P., Monks, P. S., Green, T. J., Schuepbach, E., Carpenter, L. J., Mills, G. P., Rickard, A. R., Brough, N., and Penkett, S. A.: Seasonal variation of peroxy radicals in the lower free troposphere based on observations from the FREE Tropospheric EXperiments in the Swiss Alps, Geophys. Res. Lett., 30, 1497, doi:10.1029/2003GL017122, 2003.

Zanis, P., Ganser, A., Zellweger, C., Henne, S., Steinbacher, M., and Staehelin, J.: Seasonal variability of measured ozone production efficiencies in the lower free troposphere of Central Europe, Atmos. Chem. Phys., 7, 223-236, doi:10.5194/acp-7-223-2007, 2007.

Zellweger, C., Ammann, M., Buchmann, B., Hofer, P., Lugauer, M., Ruttimann, R., Streit, N., Weingartner, E., and Baltensperger, U. Summertime $\mathrm{NO}_{\mathrm{y}}$ speciation at the Jungfraujoch, $3580 \mathrm{~m}$ above sea level, Switzerland, J. Geophys. Res., 105, 6655-6667, 2000.

Zellweger, C., Forrer, J., Hofer, P., Nyeki, S., Schwarzenbach, B., Weingartner, E., Ammann, M., and Baltensperger, U.: Partitioning of reactive nitrogen $\left(\mathrm{NO}_{\mathrm{y}}\right)$ and dependence on meteorological conditions in the lower free troposphere, Atmos. Chem. Phys., 3, 779-796, doi:10.5194/acp-3-779-2003, 2003.

Zellweger, C., Hüglin, C., Klausen, J., Steinbacher, M., Vollmer, M., and Buchmann, B.: Inter-comparison of four different carbon monoxide measurement techniques and evaluation of the long-term carbon monoxide time series of Jungfraujoch, Atmos. Chem. Phys., 9, 3491-3503, doi:10.5194/acp-9-3491-2009, 2009. 